Prepared in cooperation with the Meagher County Conservation District

\title{
A Precipitation-Runoff Model for Simulating Natural Streamflow Conditions in the Smith River Watershed, Montana, Water Years 1996-2008
}

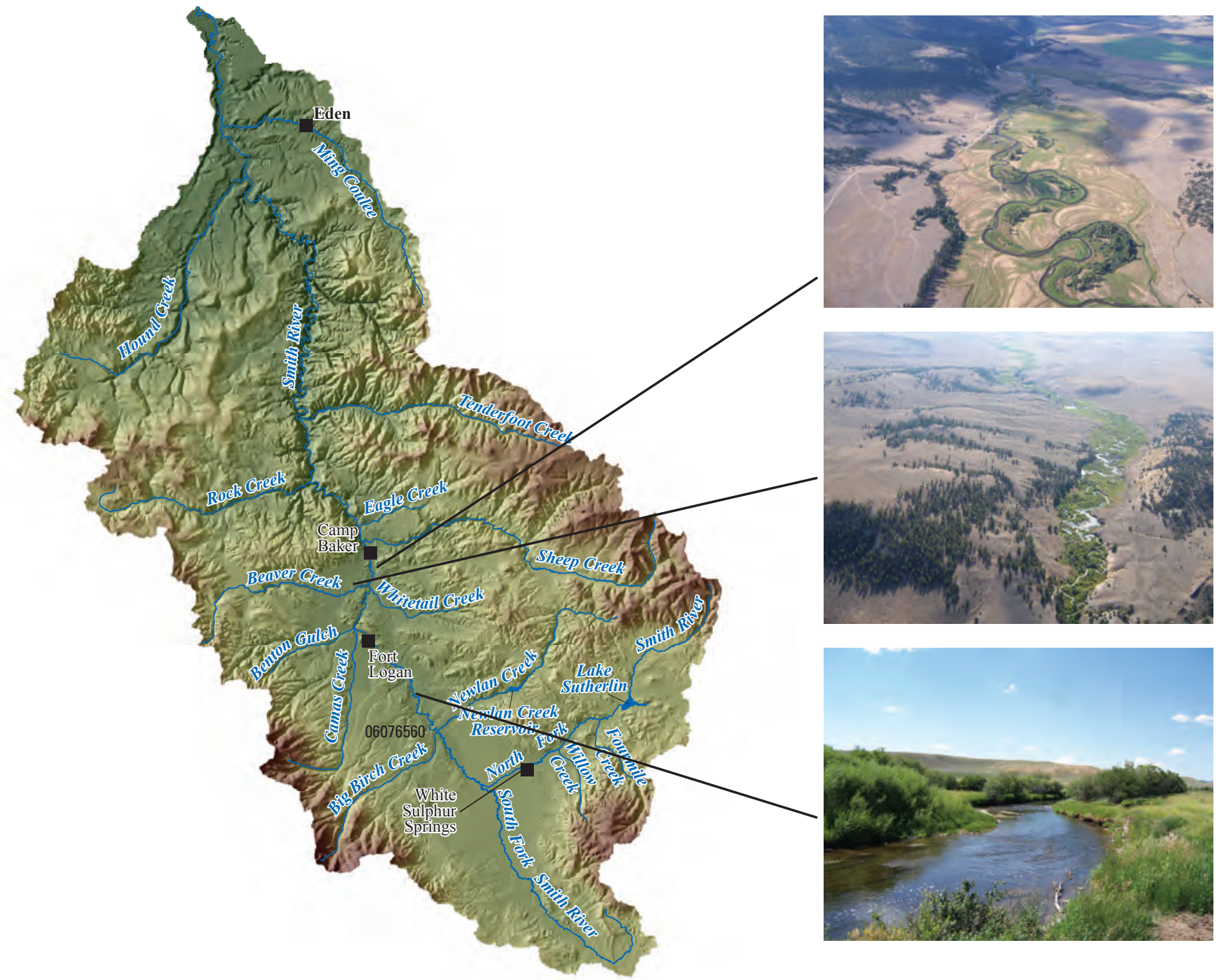

Scientific Investigations Report 2014-5125 
Cover photographs. Top, Smith River looking northwest near Camp Baker, Montana, August 2006. Middle, Beaver Creek looking west near Camp Baker, Montana, August 2006. Bottom, Smith River above Rock Springs Creek (station 06076580) near White Sulphur Springs, Montana, July 2006. Photographs by Rodney R. Caldwell, U.S. Geological Survey. 


\section{A Precipitation-Runoff Model for Simulating Natural Streamflow Conditions in the Smith River Watershed, Montana, Water Years 1996-2008}

By Katherine J. Chase, Rodney R. Caldwell, and Andrea K. Stanley

Prepared in cooperation with the Meagher County Conservation District

Scientific Investigations Report 2014-5125 


\title{
U.S. Department of the Interior SALLY JEWELL, Secretary
}

\section{U.S. Geological Survey Suzette M. Kimball, Acting Director}

\author{
U.S. Geological Survey, Reston, Virginia: 2014
}

For more information on the USGS - the Federal source for science about the Earth, its natural and living resources, natural hazards, and the environment, visit http://www.usgs.gov or call 1-888-ASK-USGS.

For an overview of USGS information products, including maps, imagery, and publications, visit http://www.usgs.gov/pubprod

To order this and other USGS information products, visit http://store.usgs.gov

Any use of trade, firm, or product names is for descriptive purposes only and does not imply endorsement by the U.S. Government.

Although this information product, for the most part, is in the public domain, it also may contain copyrighted materials as noted in the text. Permission to reproduce copyrighted items must be secured from the copyright owner.

Suggested citation:

Chase, K.J., Caldwell, R.R., and Stanley, A.K., 2014, A precipitation-runoff model for simulating natural streamflow conditions in the Smith River watershed, Montana, water years 1996-2008: U.S. Geological Survey Scientific Investigations Report 2014-5125, 26 p. plus appendix, http://dx.doi.org/10.3133/sir20145125.

ISSN 2328-0328 (online) 


\section{Contents}

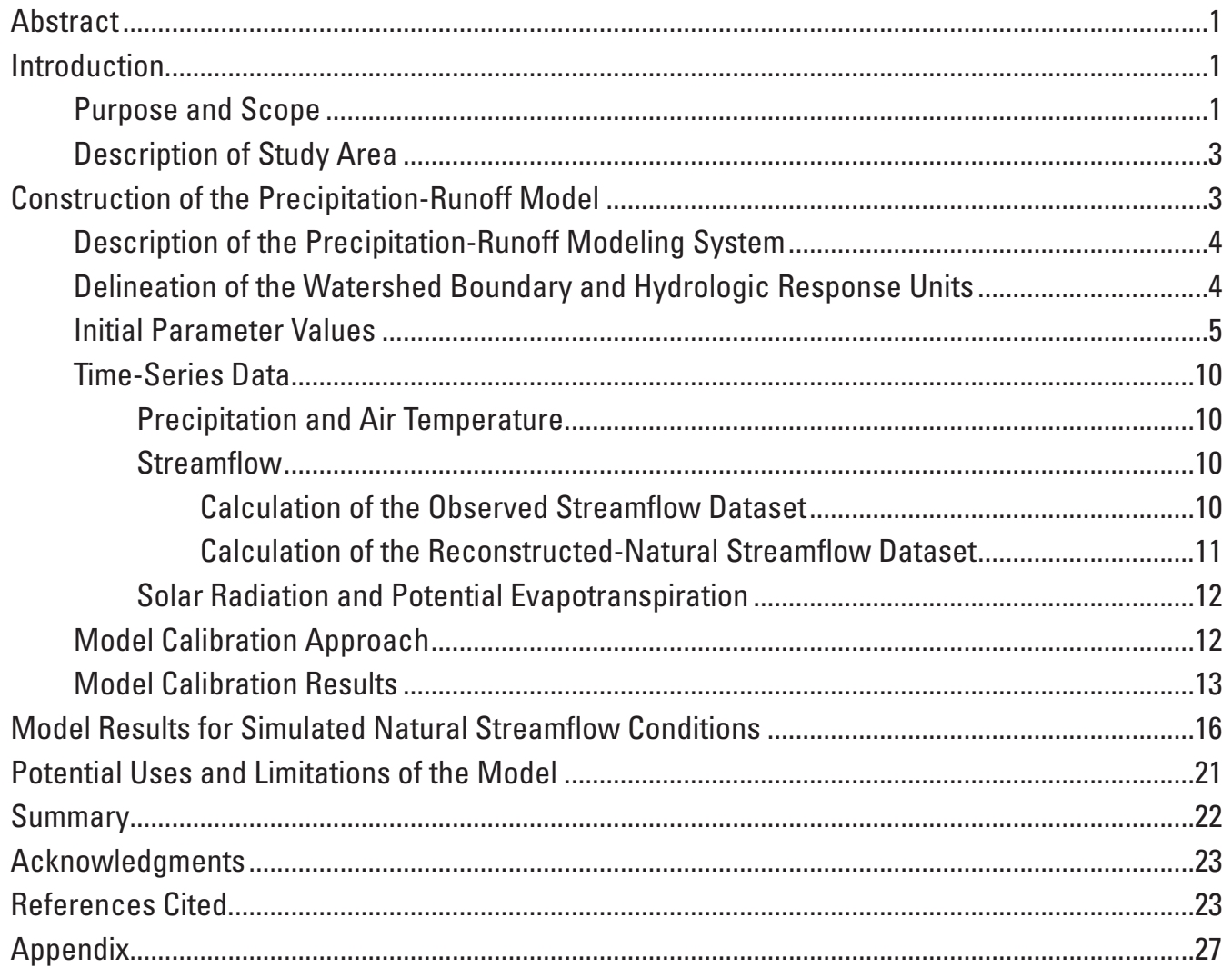

\section{Figures}

1. Map showing the location of study area and Upper Smith River watershed, Montana

2. Schematic diagram of a watershed and its climate inputs simulated by the Precipitation-Runoff Modeling System.

3. Map showing watershed boundary, hydrologic response units, and vegetation types for the precipitation-runoff model, Smith River watershed, Montana

4. Graph showing reconstructed-natural and observed daily mean streamflow for U.S. Geological Survey streamflow-gaging station Smith River near Eden, Montana

5. Graphs showing simulated-natural and reconstructed-natural daily mean streamflow for U.S. Geological Survey streamflow-gaging station Smith River near Eden, Montana.

6. Graphs showing simulated and observed climate variables for the Smith River watershed, Montana.

7. Drawing showing simulated-natural average annual water budget for the Smith River watershed, water years 1996-2008

8. Bar graph showing simulated-natural annual water budget for the Smith River watershed, water years 1996-2008 
9. Graph showing simulated-natural monthly water budget for the Smith River watershed, water years 2002-2008

10. Graph showing partition of total simulated-natural streamflow into subsurface flow and surface runoff for the Smith River watershed, Montana, water years 2002-2008

11. Graph showing simulated-natural streamflow for the Smith River watershed at Smith River at U.S. Geological Survey streamflow-gaging station Smith River near Eden, Montana, and at U.S. Geological Survey streamflow-gaging station Smith

River below Eagle Creek near Fort Logan, Montana

\section{Tables}

1. Modules used in the Precipitation-Runoff Modeling System

2. Sources, values, and ranges for selected Precipitation-Runoff Modeling System parameters for the Smith River Basin, Montana.

3. Information for selected streamflow gaging stations in and near the Smith River Basin, Montana

4. Calibration targets and parameters used in the Let Us Calibrate calibration procedure for the precipitation-runoff model.

5. Simulated-natural and reconstructed-natural mean monthly, mean annual, and mean April-July streamflow for the calibration and evaluation periods for U.S. Geological Survey streamflow-gaging station Smith River near Eden, Montana

6. Simulated-natural and reconstructed-natural annual mean streamflow for the calibration and evaluation periods for U.S. Geological Survey

streamflow-gaging station Smith River near Eden, Montana

\section{Appendix Table}

1. Historical depletion data for the Smith River, Montana, calendar years 1929-2007 


\section{Conversion Factors and Datums}

Inch/Pound to SI

\begin{tabular}{lcl}
\hline & Multiply & \multicolumn{1}{c}{ To obtain } \\
\hline inch (in.) & Length & \\
inch (in.) & 2.54 & centimeter $(\mathrm{cm})$ \\
foot (ft) & 25.4 & millimeter $(\mathrm{mm})$ \\
mile (mi) & 0.3048 & meter (m) \\
\hline & 1.609 & kilometer $(\mathrm{km})$ \\
\hline acre & Area & \\
acre & 4,047 & square meter $\left(\mathrm{m}^{2}\right)$ \\
square mile (mi $\left.{ }^{2}\right)$ & 0.004047 & square kilometer $\left(\mathrm{km}^{2}\right)$ \\
acre-foot (acre-ft) & 2.590 & square kilometer $\left(\mathrm{km}^{2}\right)$ \\
Kilo acre-foot (KAF) & 1,233 & cubic meter $\left(\mathrm{m}^{3}\right)$ \\
& $1,233,000$ & cubic meter $\left(\mathrm{m}^{3}\right)$ \\
\hline cubic foot per second (ft $3 / \mathrm{s})$ & Flow rate & \\
inch per day (in/d) & 0.02832 & cubic meter per second $\left(\mathrm{m}^{3} / \mathrm{s}\right)$ \\
\hline langley (Ly) & 25.4 & millimeter per day $\left(\mathrm{mm}^{3} / \mathrm{d}\right)$ \\
\hline
\end{tabular}

Temperature in degrees Celsius $\left({ }^{\circ} \mathrm{C}\right)$ may be converted to degrees Fahrenheit $\left({ }^{\circ} \mathrm{F}\right)$ as follows: ${ }^{\circ} \mathrm{F}=\left(1.8 \times{ }^{\circ} \mathrm{C}\right)+32$

Temperature in degrees Fahrenheit $\left({ }^{\circ} \mathrm{F}\right)$ may be converted to degrees Celsius $\left({ }^{\circ} \mathrm{C}\right)$ as follows: ${ }^{\circ} \mathrm{C}=\left({ }^{\circ} \mathrm{F}-32\right) / 1.8$

Vertical coordinate information is referenced to the North American Vertical Datum of 1988 (NAVD 88).

Horizontal coordinate information is referenced to the North American Datum of 1983 (NAD 83).

Elevation, as used in this report, refers to distance above the vertical datum.

Water year is the 12-month period from October 1 through September 30 of the following calendar year. The water year is designated by the calendar year in which it ends. For example, water year 2007 is the period from October 1, 2006 through September 30, 2007.

\section{Abbreviations}

DEM digital elevation model

HRU hydrologic response unit

GIS Geographic Information System

GSFLOW Coupled Ground-Water and Surface-Water Flow Model

LUCA Let Us Calibrate

MODFLOW Modular Ground-Water Flow Model 


$\begin{array}{ll}\text { MOVE.1 } & \text { Maintenance of Variance Extension, Type 1 } \\ \text { NS } & \text { Nash-Sutcliffe efficiency statistic } \\ \text { NCDC } & \text { National Climate Data Center } \\ \text { NOAA } & \text { National Oceanic and Atmospheric Administration } \\ \text { NRCS } & \text { Natural Resources Conservation Service } \\ \text { NRMSE } & \text { normalized root mean square error } \\ \text { NWS } & \text { National Weather Service } \\ \text { PE } & \text { potential evapotranspiration } \\ \text { PRMS } & \text { Precipitation-Runoff Modeling System } \\ \text { Reclamation } & \text { Bureau of Reclamation } \\ \text { SNOTEL } & \text { snowpack telemetry } \\ \text { SR } & \text { solar radiation } \\ \text { USGS } & \text { U.S. Geological Survey }\end{array}$

\section{Definitions}

annual mean

daily mean

mean annual

mean daily

mean monthly

monthly mean

observed streamflow

reconstructed-natural streamflow

simulated-natural streamflow arithmetic mean of all daily mean values for a single specified year

mean value for a single specified day

arithmetic mean of all annual mean values for the period of record or for a specific period of multiple years

arithmetic mean of all daily mean values for a specified day for the period of record or for a specific period of multiple years

arithmetic mean of all monthly mean values for a specified month for the period of record or for a specific period of multiple years

arithmetic mean of all daily mean values for a single specified month in a single specified year

streamflow for current conditions, including the effects of reservoir regulation, diversions, and other waterresources development throughout the watershed

streamflow for natural conditions, for which the effects of reservoir regulation, diversions, and other water-resources development have been removed

streamflow simulated using the precipitation-runoff model; effects of reservoir regulation and diversions, and other water-resources development were not included in the model 


\title{
A Precipitation-Runoff Model for Simulating Natural Streamflow in the Smith River Watershed, Montana, Water Years 1996-2008
}

\author{
By Katherine J. Chase', Rodney R. Caldwell', and Andrea Stanley²
}

\section{Abstract}

This report documents the construction of a precipitationrunoff model for simulating natural streamflow in the Smith River watershed, Montana. This Precipitation-Runoff Modeling System model, constructed in cooperation with the Meagher County Conservation District, can be used to examine the general hydrologic framework of the Smith River watershed, including quantification of precipitation, evapotranspiration, and streamflow; partitioning of streamflow between surface runoff and subsurface flow; and quantifying contributions to streamflow from several parts of the watershed.

The model was constructed by using spatial datasets describing watershed topography, the streams, and the hydrologic characteristics of the basin soils and vegetation. Timeseries data (daily total precipitation, and daily minimum and maximum temperature) were input to the model to simulate daily streamflow. The model was calibrated for water years 2002-2007 and evaluated for water years 1996-2001. Though water year 2008 was included in the study period to evaluate water-budget components, calibration and evaluation data were unavailable for that year. During the calibration and evaluation periods, simulated-natural flow values were compared to reconstructed-natural streamflow data. These reconstructednatural streamflow data were calculated by adding Bureau of Reclamation's depletions data to the observed streamflows. Reconstructed-natural streamflows represent estimates of streamflows for water years 1996-2007 assuming there was no agricultural water-resources development in the watershed. Additional calibration targets were basin mean monthly solar radiation and potential evapotranspiration.

The model estimated the hydrologic processes in the Smith River watershed during the calibration and evaluation periods. Simulated-natural mean annual and mean monthly flows generally were the same or higher than the reconstructed-natural streamflow values during the calibration period, whereas they were lower during the evaluation period.

\footnotetext{
${ }^{1}$ U.S. Geological Survey.
}

${ }^{2}$ Great West Engineering of Helena, Montana.
The shape of the annual hydrographs for the simulated-natural daily streamflow values matched the shape of the hydrographs for the reconstructed-natural values for most of the calibration period, but daily streamflow values were underestimated during the evaluation period for water years 1996-1998.

The model enabled a detailed evaluation of the components of the water budget within the Smith River watershed during the water year 1996-2008 study period. During this study period, simulated mean annual precipitation across the Smith River watershed was 16 inches, out of which 14 inches evaporated or transpired and 2 inches left the basin as streamflow. Per the precipitation-runoff model simulations, during most of the year, surface runoff rarely (less than 2 percent of the time during water years 2002-2008) makes up more than 10 percent of the total streamflow. Subsurface flow (the combination of interflow and groundwater flow) makes up most of the total streamflow (99 or more percent of total streamflow for 71 percent of the time during water years 2002-2008).

\section{Introduction}

The Smith River watershed is a valuable agricultural and recreational area in Meagher and Cascade Counties in westcentral Montana (fig. 1). In 2005, the U.S. Geological Survey (USGS), in cooperation with the Meagher County Conservation District, began a multiyear study of the Smith River watershed. This study was designed to expand the knowledge of the hydrologic system through a systematic program of data collection and compilation, research, and analysis. The study included collection of hydrologic data (Nilges and Caldwell, 2012), groundwater and surface-water interaction analyses (Caldwell and Eddy-Miller, 2013), and precipitation-runoff modeling (this study).

\section{Purpose and Scope}

The purpose of this report is to document the construction and results of a precipitation-runoff model for the Smith River watershed in west-central Montana. The distributed-parameter, 


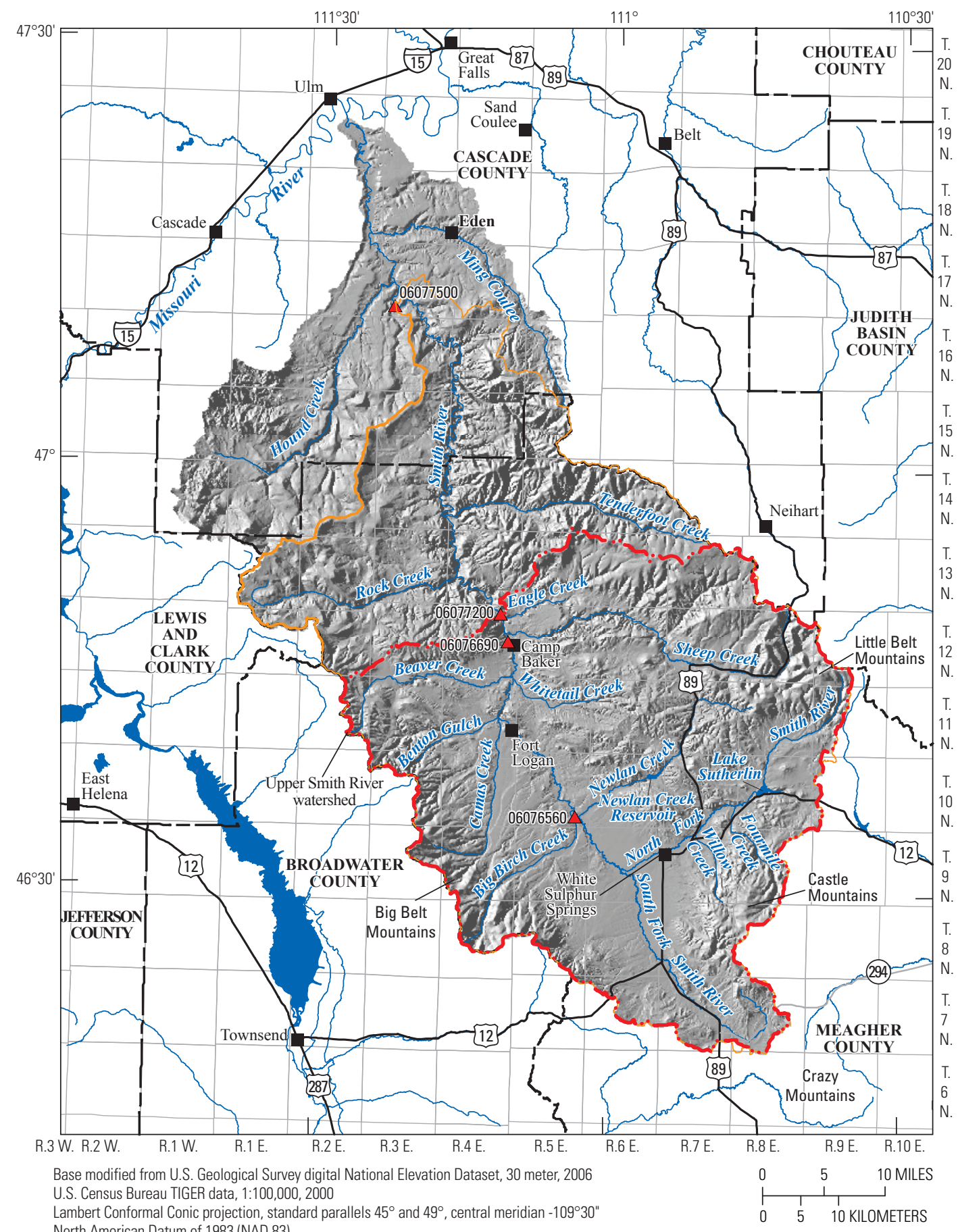

Lambert Conformal Conic projection, standard paralles $45^{\circ}$ and $49^{\circ}$, central meridian - $109^{\circ} 30^{\circ}$ North American Datum of 1983 (NAD 83)

\section{EXPLANATION}

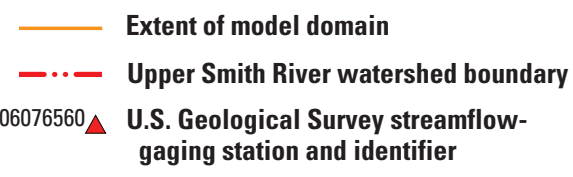

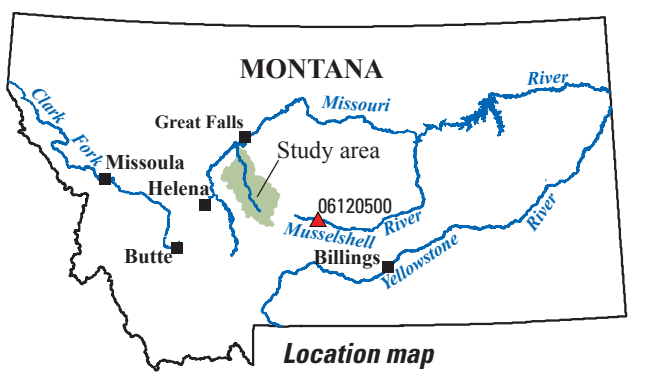

Figure 1. Location of study area and Upper Smith River watershed, Montana. 
physically-based Precipitation-Runoff Modeling System (PRMS; U.S. Geological Survey, 2012b; Leavesley and others, 1983; Leavesley and others, 2006; Markstrom and others, 2008) was used to simulate the precipitation-runoff processes of the Smith River watershed for the study period (water years 1996-2008). Summary tables and graphs of parameter values, model results, and data sources are included in this report.

This report describes the calibration of the model by using data from water years 2002-2007 and the evaluation of the model by using data from water years 1996-2001. (Though water year 2008 was included in the study period to evaluate water-budget components, reconstructed-natural streamflow data were not available for water year 2008 for calibration or evaluation.) Simulated-natural and reconstructednatural annual mean, mean monthly, and daily mean streamflow at USGS streamflow-gaging station (station identification number 06077500) Smith River near Eden, Montana, (fig. 1), as well as basin mean monthly solar radiation (SR) and potential evapotranspiration data (PE), were compared during model calibration and evaluation.

\section{Description of Study Area}

The Smith River is a tributary to the Missouri River with a watershed encompassing about 2,000 square miles $\left(\mathrm{mi}^{2}\right)$ in Meagher and Cascade counties of west-central Montana. The model domain includes the $1,594 \mathrm{mi}^{2}$ drainage area above USGS streamflow-gaging station (station identification number 06077500) Smith River near Eden, Montana (fig. 1).

The Smith River watershed lies within the Northern Rocky Mountains Physiographic Division described by Fenneman and Johnson (1946) and is characterized by rugged mountains and flat and incised river valleys. Surrounding mountain ranges include the Castle Mountains to the east, the Little Belt Mountains to the north and east, the Big Belt Mountains to the west, and the Crazy Mountains to the south. Elevations in the watershed range from about 9,500 feet (ft) in the Big Belt Mountains to about 3,320 ft at the mouth of the Smith River near Ulm, Montana (fig. 1). The elevation of USGS streamflow-gaging station (station identification number 06077500) Smith River near Eden, Montana is 3,500 ft.

The watershed has a low-density rural population and most (about 48 percent) of the total area land cover in the watershed is grass rangeland (U.S. Geological Survey, 2000). Conifer forests at the higher elevations in the watershed account for 39 percent of the total area. The more arid, lower elevation parts of the watershed are dominated by grasslands and riparian vegetation near the streams. Cultivated farm lands are also present in the lower elevations, adjacent to the Smith River and its tributaries.

The climate in the Smith River watershed is generally semiarid with some semi-humid areas in the higher mountains. Summer temperatures are mild in the valleys with cooler temperatures in the higher mountains. Winters are cold with a thick snowpack that accumulates in the mountains. Monthly mean temperatures during the study period (water years 1996-2008) near White Sulphur Springs (fig. 1) ranged from 14.7 degrees Fahrenheit $\left({ }^{\circ} \mathrm{F}\right)\left[-9.6\right.$ degrees Celsius $\left.\left({ }^{\circ} \mathrm{C}\right)\right]$ in January 1996 to $72.3^{\circ} \mathrm{F}\left(22.4^{\circ} \mathrm{C}\right)$ in July 2007 (National Climatic Data Center, 2011). Precipitation varies both spatially and temporally. Average annual precipitation (1971-2000) ranges from less than 12 inches (in) per year in the lower elevations of the watershed to the west and northwest of White Sulphur Springs to more than 40 in per year in the Castle, Little Belt, and Big Belt Mountains (fig. 1; Oregon State University PRISM Group, 2006; Phil Farnes, Snowcap Hydrology, written commun., 2007).

The Smith River is the primary stream that drains the watershed. The Smith River originates about 3 miles (mi) southwest of White Sulphur Springs at the confluence of the North Fork and South Fork Smith Rivers (fig. 1). The North Fork Smith River begins in the Little Belt Mountains to the northeast of White Sulphur Springs and flows for nearly $40 \mathrm{mi}$ to the southwest as it gains tributary inflow from both the Little Belt and the Castle Mountains before joining the South Fork Smith River. The South Fork Smith River begins in the Castle Mountains, and flows to the west and northwest for about $38 \mathrm{mi}$. The South Fork Smith River gains tributary inflow from both the Castle and Big Belt Mountains, and from an unsealed artesian well before meeting the North Fork Smith River. Together, the North Fork and South Fork Smith Rivers form the Smith River, which flows roughly northwest for about $125 \mathrm{mi}$ until it ultimately joins the Missouri River near Ulm, Montana. In addition to the North and South Forks of the Smith River, major tributaries within the model domain include Big Birch Creek, Camas Creek, and Rock Creek from the Big Belt Mountains, and Newlan Creek, Sheep Creek, Eagle Creek, and Tenderfoot Creek from the Little Belt Mountains. Two reservoirs with more than 500 acre-feet (acre$\mathrm{ft}$ ) capacities are in the upper part of the Smith watershed (Caldwell and Eddy-Miller, 2013; Montana Natural Resources Information System, 2010); Lake Sutherlin on the North Fork Smith River (14,200 acre-ft capacity) and Newlan Creek Reservoir on Newlan Creek (15,600 acre-ft capacity).

\section{Construction of the Precipitation- Runoff Model}

The Precipitation-Runoff Modeling System (PRMS) was used to simulate the precipitation-runoff characteristics of the Smith River watershed for the study period (water years 19962008). This model was constructed, calibrated, and evaluated to represent natural streamflow conditions in the Smith River watershed. These natural streamflow conditions are herein defined as the streamflow for which the effects of agricultural water-resources development, such as diversions and irrigation, have been removed. However, streamflows were not modified to remove effects of deforestation or road and building construction in the watershed. The model was calibrated to 
represent annual mean, mean annual, mean monthly, and daily mean natural streamflow reconstructed from data collected at the USGS streamflow-gaging station (station identification number 06077500) Smith River near Eden, Montana, and mean monthly solar radiation and potential evapotranspiration averaged across the Smith River watershed. Simulated and observed values of streamflow, solar radiation, and potential evapotranspiration were compared to calibrate the model and assess the ability of the model to accurately simulate the hydrologic response to precipitation events for the watershed.

\section{Description of the Precipitation-Runoff Modeling System}

The PRMS is a distributed-parameter, physically-based precipitation-runoff model (U.S. Geological Survey, 2012b; Leavesley and others, 1983; Leavesley and others, 1996; Markstrom and others, 2008; U.S. Geological Survey, 2012b) that uses different modules (subroutines) to simulate daily hydrologic and energy processes occurring in a watershed. The watershed surface was divided into hydrologic response units (HRUs). HRUs are smaller areas of the watershed assumed to have a uniform response to precipitation, evaporation, transpiration, and snow processes.

The PRMS is conceptualized as a series of theoretical reservoirs (impervious zone, soil zone, subsurface, and groundwater) that contribute to runoff (fig. 2). Streamflow is partitioned between surface runoff, interflow, and groundwater flow (fig. 2). Surface runoff and infiltration are simulated in the srunoff_smidx module within PRMS (table 1, fig. 2). Water that is simulated as infiltration is stored in pores within the soil matrix in the soil-zone reservoir (and removed by evaporation and transpiration) until soil moisture storage capacities are exceeded. Excess water is then divided between interflow and the groundwater reservoir (fig. 2). Interflow (through the unsaturated-saturated zones in the subsurface reservoir) and groundwater flow (through the saturated zone in the groundwater reservoir) are simulated within the soilzone and gwflow modules within PRMS (table 1).

Interflow represents water moving laterally to the stream through pores in the soil in the subsurface reservoir (intergranular spaces between grains of clay, silt, sand, and gravel), perched atop a less permeable soil horizon (Markstrom and others, 2008). Interflow also can include water moving through larger macropores in the soil (Selker and others, 1999). Macropores can be caused by cracks from seasonal shrinking and swelling of the soil, by holes from decaying plant matter such as roots and leaf litter, by holes from animal activity such as worms and gophers, and by cracks from landscape altering events such as earthquakes. Interflow is simulated as moving relatively rapidly to a stream channel.

Infiltrated water in excess of soil moisture capacities that does not become interflow enters the theoretical groundwater reservoir (fig. 2). This water in the theoretical groundwater reservoir is available to flow laterally to the stream. This groundwater flow typically often is described as base flow, or that part of stream discharge that is not attributable to direct runoff from precipitation or melting snow (Jackson, 1997). Groundwater is simulated as moving relatively slowly to the stream channel.

Unlike groundwater-flow models such as the Modular Ground-Water Flow Model (MODFLOW; Harbaugh, 2005), or coupled groundwater and surface-water flow models such as the Coupled Ground-Water and Surface-Water Flow Model (GSFLOW; Markstrom and others, 2008), the PRMS model does not include partial differential equations that describe the movement of groundwater. Instead, the PRMS model represents groundwater flow by using empirical and simplified equations that do not consider the effect of local geology and surface-water interactions (Markstrom and others, 2008).

A water balance, or tally of volumes of water entering and leaving each HRU, is calculated each day. Rainfall and snowmelt add water to an HRU, and processes such as evaporation, transpiration, and sublimation remove water from an HRU. An energy balance, or tally of amounts of energy entering and leaving each HRU, is computed twice each day. Air temperature (air temperature herein is simply referred to as "temperature") and solar radiation add energy to an HRU, and evaporation, snowmelt, and sublimation from the snowpack remove energy from an HRU (fig. 2). The sum of the water balances of all HRUs, weighted by unit area, equals the daily watershed hydrologic response (Hay and others, 2006). The physical processes represented by the Smith River watershed PRMS model are illustrated in figure 2, and the 15 modules included in the model are described in table 1.

The Smith River model simulates daily mean streamflow by using two types of input files. The parameter input file contains values of parameters that describe the watershed topography, the stream network, correction factors for the precipitation and temperature data, and the hydrologic characteristics of soils and vegetation in the watershed. The time-series data input files contain daily precipitation data, and daily minimum and maximum temperature data for each HRU in the Smith River watershed, as well as streamflow data for streamflowgaging stations along the Smith River.

\section{Delineation of the Watershed Boundary and Hydrologic Response Units}

The model boundary (or domain) for the Smith River watershed was delineated by using the Geographic Information System (GIS) Weasel (Viger and Leavesley, 2007), which is a tool that helps process, organize, and extract data from spatial datasets for models like the PRMS. The GIS Weasel used a digital elevation model (DEM), with a cell size of $308 \mathrm{ft}$ by $308 \mathrm{ft}$, from the USGS National Elevation Dataset (U.S. Geological Survey, 1999) to delineate the model boundary and to divide the watershed upstream from the USGS streamflow-gaging station (station identification number 06077500) Smith River near Eden, Montana into 88 HRUs 


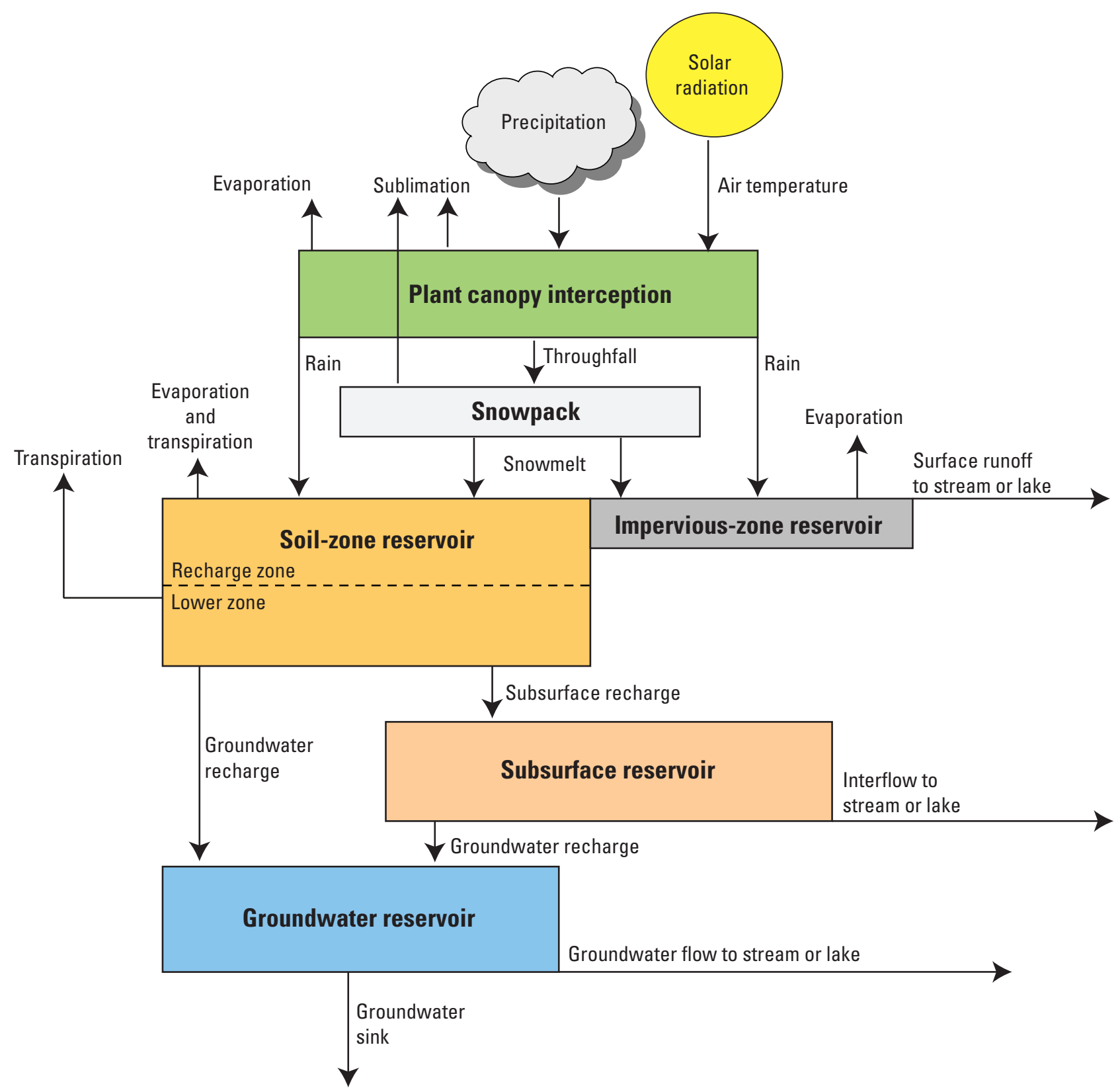

Figure 2. A watershed and its climate inputs (precipitation, air temperature, and solar radiation) simulated by the Precipitation-Runoff Modeling System. Figure modified from Leavesley and others (1983), and Markstrom and others (2008).

by using methods described on page 8 in Chase (2011). The HRUs within the model ranged in size from 1.9 to $62 \mathrm{mi}^{2}$ (fig. 3).

\section{Initial Parameter Values}

Initial parameter values were obtained by using the GIS Weasel or from default PRMS values (table 2; USGS, 2012b; Leavesley and others, 1983; Leavesley and others, 1996; Markstrom and others, 2008). Some of the initial parameter values, such as those describing topography and vegetation types for each HRU, were calculated from existing datasets and were not adjusted during the calibration process. Other parameter values, such as those describing water-holding capacity of soils in each HRU, were more difficult to estimate based on existing information and were adjusted during the calibration process.

Parameter values that describe slope, aspect, and elevation for each HRU were extracted from the DEM by using the GIS Weasel (table 2). The GIS Weasel also was used to calculate initial parameter values from datasets for soils (Wolock, 1997; U.S. Department of Agriculture, Natural Resources Conservation Service, 1994), land cover (Zhu, 1994), and 
Table 1. Modules used in the Precipitation-Runoff Modeling System.

[U.S. Geological Survey (2012b), Markstrom and others (2008). HRU, hydrologic response unit]

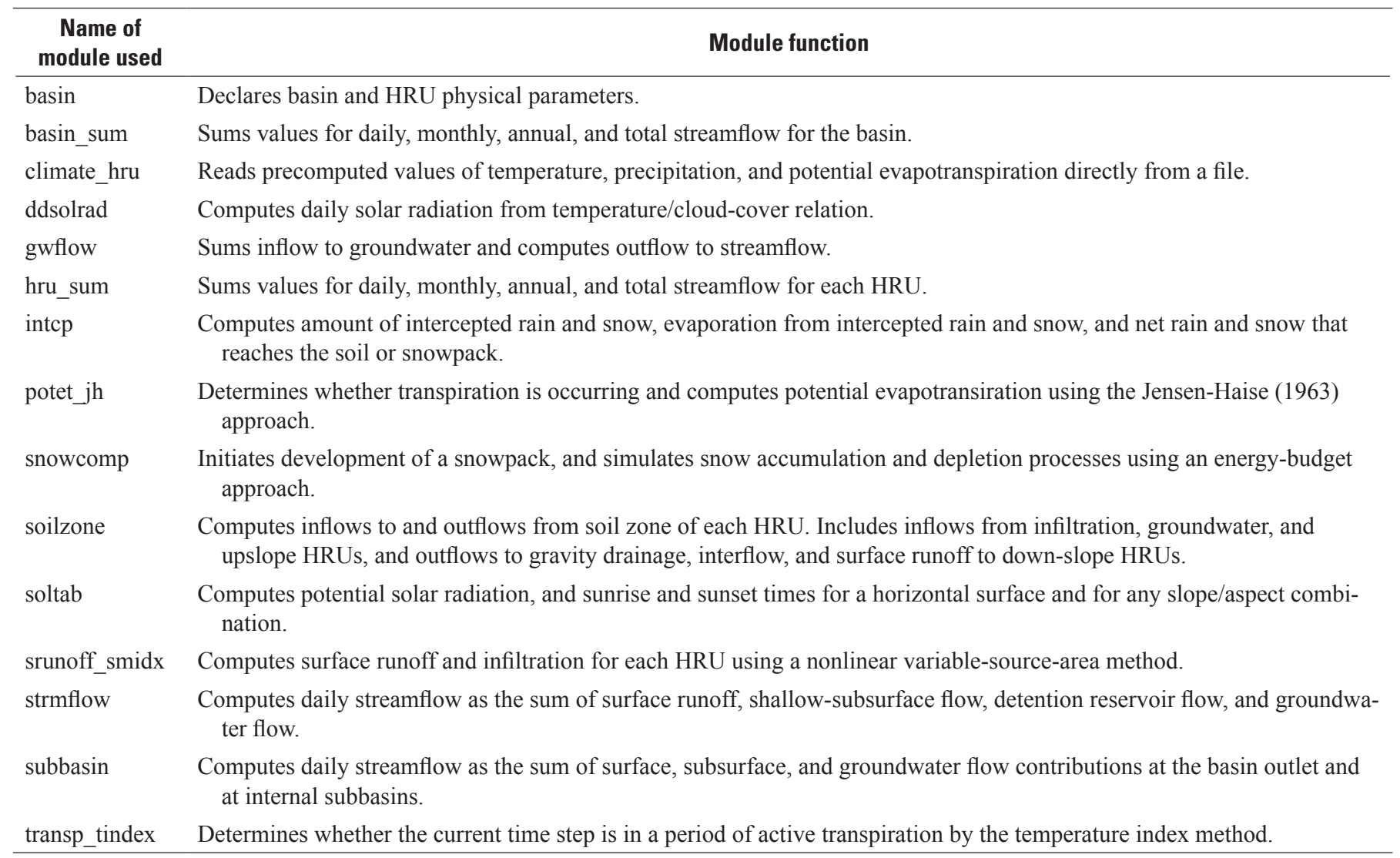

forest type and density (Powell and others, 1993; Zhu and Evans, 1994). The GIS Weasel parameterization process and datasets are described in detail by Viger and Leavesley (2007). Some initial parameter values, such as the Jensen-Haise (Jensen and Haise, 1963) PE coefficients, and coefficients used to estimate groundwater routing and storage, were default values (USGS, 2012b; Leavesley and others, 1983; Leavesley and others, 1996; Markstrom and others, 2008).

Some parameter values derived from the GIS datasets were adjusted during calibration, whereas others were not (table 2). For example, soils information from Wolock (1997) was used to estimate initial values for the parameter that describes the maximum water depth for the soil recharge zone (soil_rechr_max, table 2). Initial values of this parameter were approximated as a function of the rooting depth of dominant vegetation in each HRU (Viger and Leavesley, 2007) and ranged from 1.224 to 2.639 in. These values were adjusted during calibration (to the final values shown in table 2) because of uncertainties in the rooting-depth estimates. Landcover data from Zhu (1994) were used to estimate the most hydrologically important cover type (cov_type, table 2) on each HRU. The cover types used for the Smith River watershed were grasses, shrubs, and trees (fig. 3, table 2; cov_ types $=1,2$, and 3 , respectively). Because the "tree" cover type is hydrologically important in the PRMS model calculations, if more than 20 percent of an HRU area was covered by trees, then the HRU cov_type was set to 3 (Viger and Leavesley, 2007). Remaining HRUs with less than 20 percent tree cover were classified as "grass" or "shrub" based on the land cover data. These cover type values were not changed during calibration.

Parameters describing the interflow and groundwaterflow processes (table 2) initially were estimated based on soils data or defaults from other PRMS studies (Markstrom and others, 2008) and then adjusted during model calibration. The parameters fastcoef_lin, fastcoef_sq, pref_flow_den, slowcoef_lin, slowcoef_sq, soil_moist_max, soil_rechr_max, ssr2gw_exp, and ssr2gw_rate are used within PRMS, in the soilzone module, to simulate interflow. These parameters initially were estimated as defaults, or from soil data from U.S. Department of Agriculture (2013a and 2013b), and then adjusted during model calibration. The parameter gwflow_ coef is used within PRMS, in the gwflow module, as a groundwater-flow routing coefficient to simulate groundwater flow. Typically gwflow_coef is estimated based on the slope of the receding limb of the annual hydrograph (Linsley and others, 1982). However, measured natural flow hydrographs were unavailable for this study, so gwflow_coef was estimated based on soils information (U.S. Department of Agriculture, 2013a and 2013b) and adjusted during calibration. 


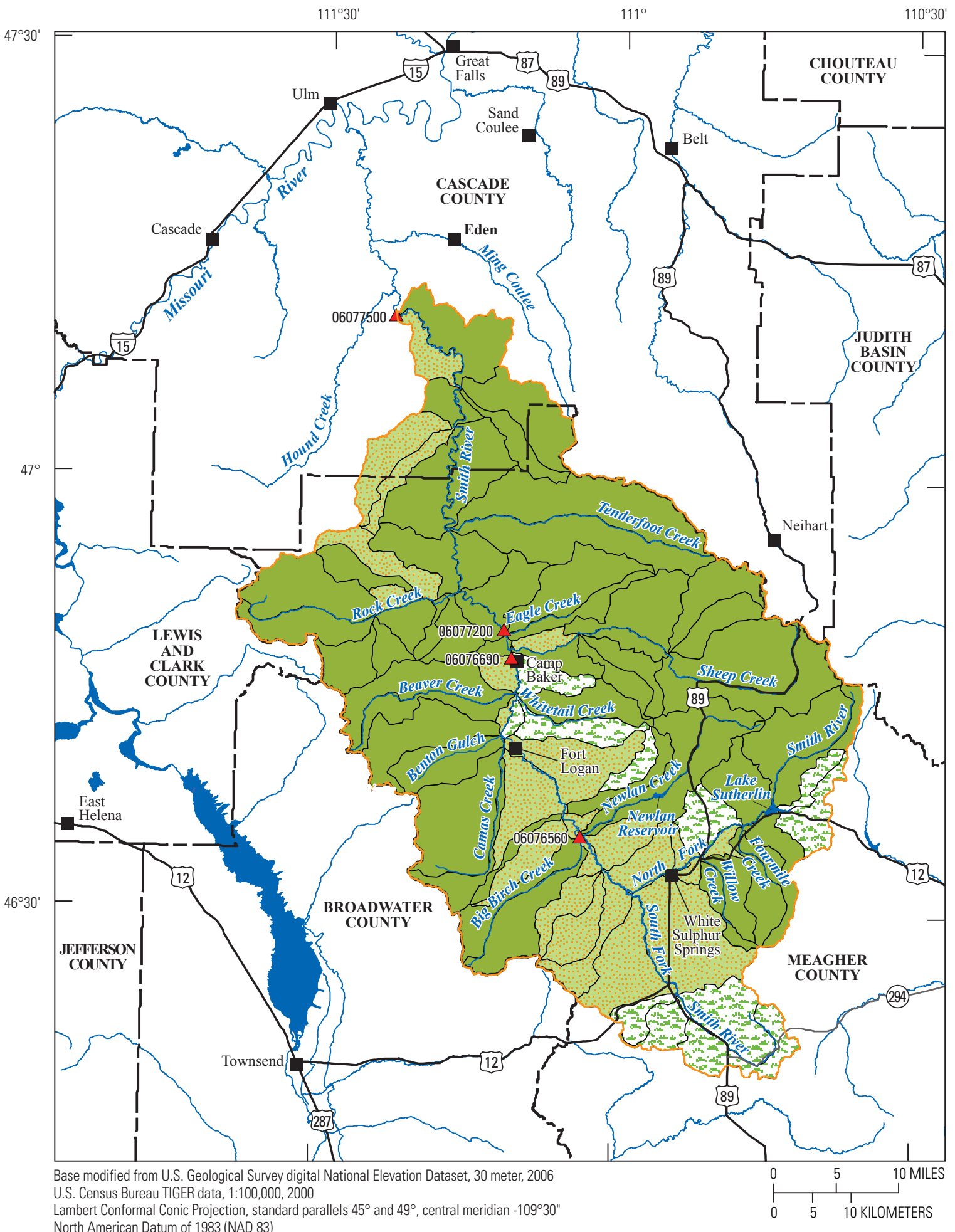

EXPLANATION

Hydrologic response units (HRUs) and vegetation type-HRUs are subbasins within the Precipitation-Runoff Modeling System. Each subbasin is assumed to have a relatively uniform response to precipitation and snowmelt

Extent of model domain

$06076560 \Delta$ U.S. Geological Survey streamflowgaging station and identifier

Grass

Figure 3. Watershed boundary, hydrologic response units, and vegetation types for the precipitation-runoff model, Smith River watershed, Montana. 
Table 2. Sources, values, and ranges for selected Precipitation-Runoff Modeling System parameters for the Smith River Basin, Montana.

\begin{tabular}{|c|c|c|c|c|}
\hline \multirow{2}{*}{ Model parameter } & \multirow{2}{*}{ Description of parameter } & \multirow{2}{*}{$\begin{array}{l}\text { Value or range of } \\
\text { values (or cover type) } \\
\text { used in model }{ }^{1}\end{array}$} & \multicolumn{2}{|c|}{$\begin{array}{l}\text { Source of parameter } \\
\text { values }\end{array}$} \\
\hline & & & $\begin{array}{c}\text { GIS } \\
\text { derived }^{2}\end{array}$ & Calibrated $^{3}$ \\
\hline \multicolumn{5}{|c|}{ HRU (spatially distributed) parameters } \\
\hline cov_type & Vegetation cover type [bare soil (0), grasses (1), shrubs (2), trees (3)] & Grasses, shrubs, trees & $\mathrm{X}$ & \\
\hline covden_sum & Vegetation cover density (decimal percent) for summer & $001-0.668$ & $\mathrm{X}$ & \\
\hline covden_win & Vegetation cover density (decimal percent) for winter & $0-0.618$ & $\mathrm{X}$ & \\
\hline fastcoef_lin & Linear preferential-flow routing coefficient & $0.006-0.144$ & & $\mathrm{X}$ \\
\hline fastcoef_sq & Non-linear preferential-flow routing coefficientl & 0.15 & & $\mathrm{X}$ \\
\hline gwflow_coef & Groundwater rounding coefficient to obtain the groundwater flow contribution to streamflow & $0.004-0.096$ & & $\mathrm{X}$ \\
\hline gwstor_init & Storage in each groundwater reservoir at the beginning of the simulation (in.) & 0.205 & & $\mathrm{X}$ \\
\hline hru_area & HRU area (acres) & $1,217-39,892$ & $\mathrm{X}$ & \\
\hline hru_aspect & HRU aspect (degrees) & $0-353$ & $\mathrm{X}$ & \\
\hline hru_elev & Mean HRU elevation (ft) & $1,299-2,142$ & $\mathrm{X}$ & \\
\hline hru_percent_impervious & HRU impervious area as a percent of the total HRU area & $0-3$ & $\mathrm{X}$ & \\
\hline hru_slope & HRU slope in decimal percent (vertical ft/horizontal ft) & $0.032-0.35$ & $\mathrm{X}$ & \\
\hline jh_coef_HRU & $\begin{array}{l}\text { Air temperature coefficient used in the Jensen-Haise (Jensen and Haise, 1963) potential } \\
\text { evapotranspiration computations for each HRU }\end{array}$ & $15.178-17.792$ & & $\mathrm{X}$ \\
\hline pref_flow_den & Preferential-flow pore density & 0.1 & & \\
\hline rad_trncf & Transmission coefficient for short-wave radiation through the winter canopy (decimal percent) & $0.164-0.991$ & $\mathrm{X}$ & \\
\hline slowcoef_lin & Linear gravity-flow resrvoir routing coefficient & $0.014-0.106$ & & $\mathrm{X}$ \\
\hline slowcoef_sq & Non-linear gravity-flow resrvoir routing coefficient & 0.008 & & $\mathrm{X}$ \\
\hline smidx_coef & Coefficient in the nonlinear surface-runoff contributing-area algorithm & 0 & & $\mathrm{X}$ \\
\hline smidx_exp & Exponent in the nonlinear surface-runoff contributing-area algorithm & 0.201 & & $\mathrm{X}$ \\
\hline snarea_thresh & Maximum snow-water equivalent below which the snow-covered area depletion curve is applied (in.) & $0-13.8$ & & $\mathrm{X}$ \\
\hline snow_intep & Snow interception storage capacity for the major vegetation type on an HRU (in.) & $0.018-0.095$ & $\mathrm{X}$ & \\
\hline soil2gw_max & $\begin{array}{l}\text { Maximum amount of soil water excess for an HRU that is routed directly to the associated } \\
\text { groundwater reservoir each day (in.) }\end{array}$ & 0.06 & & $\mathrm{X}$ \\
\hline soil_moist_max & Maximum available water-holding capacity of soil profile (in.) & $5.887-7.466$ & & $\mathrm{X}$ \\
\hline soil_rechr_max & Maximum value for available water in the soil recharge zone (in.) & $0.345-1.649$ & & $\mathrm{X}$ \\
\hline soil_type & HRU soil type (sand, loam, or clay) & Loam & $\mathrm{X}$ & \\
\hline ssr2gw_exp & Coefficient to route water from subsurface to groundwater & 1 & & $\mathrm{X}$ \\
\hline
\end{tabular}


Table 2. Sources, values, and ranges for selected Precipitation-Runoff Modeling System parameters for the Smith River Basin, Montana.—Continued

[HRU, hydrologic response unit; in., inches; ft, feet; GIS, Geographic Information System]

\begin{tabular}{|c|c|c|c|c|}
\hline \multirow{2}{*}{ Model parameter } & \multirow{2}{*}{ Description of parameter } & \multirow{2}{*}{$\begin{array}{c}\text { Value or range of } \\
\text { values (or cover type) } \\
\text { used in model' }\end{array}$} & \multicolumn{2}{|c|}{$\begin{array}{l}\text { Source of parameter } \\
\text { values }\end{array}$} \\
\hline & & & $\begin{array}{c}\text { GIS } \\
\text { derived }^{2}\end{array}$ & Calibrated $^{3}$ \\
\hline \multicolumn{5}{|c|}{ HRU (spatially distributed) parameters-Continued } \\
\hline ssr2gw_rate & Coefficient to route water from subsurface to groundwater & $0.004-0.165$ & & $\mathrm{X}$ \\
\hline srain_intcp & Summer interception storage capacity for the major vegetation type on an HRU (in.) & $0.017-0.048$ & $\mathrm{X}$ & \\
\hline wrain_intcp & Winter rain interception storage capacity for the major vegetation type on an HRU (in.) & $0.017-0.048$ & $\mathrm{X}$ & \\
\hline \multicolumn{5}{|c|}{ Selected spatially non-distributed parameters } \\
\hline adjmix_rain & Monthly factor to adjust rain proportion in a mixed rain/snow event (decimal percent) & 0 & & $\mathrm{X}$ \\
\hline cecn_coef & Convection condensation energy coefficient & 0.005 & & $\mathrm{X}$ \\
\hline dday_intcp & Monthly intercept in the temperature degree-day relation $\left(\right.$ dday $\left.^{4}\right)$ & $-39.1-9.95$ & & $\mathrm{X}$ \\
\hline emis_noppt & Emissivity of air on days without precipitation (decimal fraction) & 0.757 & & $\mathrm{X}$ \\
\hline freeh2o_cap & $\begin{array}{l}\text { Free-water holding capacity of snowpack (expressed as decimal fraction of total snowpack water } \\
\text { equivalent) }\end{array}$ & 0.199 & & $\mathrm{X}$ \\
\hline jh_coef & $\begin{array}{l}\text { Monthly air temperature coefficient used in the Jensen-Haise (Jensen and Haise, 1963) potential } \\
\text { evapotranspiration computations }\end{array}$ & $0.005-0.016$ & & $\mathrm{X}$ \\
\hline potet_sublim & Proportion of potential evapotranspiration sublimated from snow surface (decimal fraction) & 0.101 & & $\mathrm{X}$ \\
\hline rain_sub_adj & Monthly (January to December) rain adjustment factor to measured precipitation for each subbasin & $0.505-0.998$ & & $\mathrm{X}$ \\
\hline snow_sub_adj & Monthly (January to December) snow adjustment factor to measured precipitation for each subbasin & $0.503-1.00$ & & $\mathrm{X}$ \\
\hline tmax_allrain & $\begin{array}{l}\text { Monthly maximum temperature (degrees Fahrenheit) above which all precipitation is simulated as } \\
\text { rain }\end{array}$ & $62.67-72.89$ & & $\mathrm{X}$ \\
\hline tmax_allsnow & $\begin{array}{l}\text { Monthly maximum temperature (degrees Fahrenheit) below which all precipitation is simulated as } \\
\text { snow }\end{array}$ & 35 & & $\mathrm{X}$ \\
\hline tmax_index & $\begin{array}{l}\text { Monthly index temperature used to determine precipitation adjustments to solar radiation (degrees } \\
\text { Fahrenheit) }\end{array}$ & $54.05-86.39$ & & $\mathrm{X}$ \\
\hline
\end{tabular}

${ }^{1}$ Where units are not shown, parameters are dimensionless.

${ }^{2}$ Computed using the GIS Weasel (Viger and Leavesley, 2007) Geographic Information System (GIS) from digital coverages, not changed during calibration.

${ }^{3}$ Parameters that (a) cannot be estimated from available data and are adjusted during calibration or (b) have initial estimates from measured or published data that were adjusted during calibration.

${ }^{4}$ degree-day (dday) is a PRMS modeling unit used in the equations to estimate solar radiation (Markstrom and others, 2008). 


\section{Time-Series Data}

Observed time-series data are used in the model for model input, calibration and evaluation. Daily precipitation and minimum and maximum air-temperature data are required input data for the model to simulate streamflow. In addition, observed streamflow, solar radiation, snow-water equivalence, and potential evapotranspiration data can be used for model calibration. The time-series data used in the model were obtained from the following sources: the USGS, the National Oceanic and Atmospheric Administration (NOAA), the National Climate Data Center (NCDC), and the U.S. Department of Agriculture, Natural Resources Conservation Service (NRCS), National Water and Climate Center, Snow Survey, and Water Supply Forecasting Program.

\section{Precipitation and Air Temperature}

Precipitation and air-temperature data used in the model were obtained from Daymet (Thornton and others, 2012). Daymet uses meteorological data from NCDC climate stations and NRCS snowpack telemetry (SNOTEL) stations to generate daily gridded surfaces of air temperature and precipitation (as well as other meteorological variables) over the United States (Thornton and others, 1997). The data were downloaded for each HRU in the Smith River watershed by using the USGS GeoData Portal (Blodgett and others, 2011; Lauren Hay, U.S. Geological Survey, written commun., 2012). Three data files from Daymet were used as input to the precipitationrunoff model: one containing daily total precipitation for each HRU, one containing maximum daily air temperature for each $\mathrm{HRU}$, and one containing minimum daily air temperature for each HRU.

\section{Streamflow}

Four types of daily mean streamflow data are described in this report: measured, observed, reconstructed-natural, and simulated-natural. Measured streamflow data are obtained from USGS streamflow-gaging stations (table 3; U.S. Geological Survey, 2012a). Observed streamflow data include the measured streamflow data as well as synthesized streamflow data for periods when USGS streamflow-gaging station data are not available. Both measured and observed streamflow data reflect actual streamflow conditions; these data include effects of reservoir regulation, diversions, and other water-resources development throughout the Smith River watershed. Reconstructed-natural streamflow data reflect natural conditions for which the effects of water-resources development have been removed. These data were calculated by adding agricultural depletions data (discussed in the section "Calculation of the Reconstructed-Natural Streamflow Dataset") to the observed streamflow data. Finally, simulated-natural streamflow data were simulated by using the model.

Data from streamflow-gaging station (station identification number 06077500; table 3) Smith River near Eden, Montana were used for model calibration and evaluation. Data from other streamflow-gaging stations in the Smith River watershed (station identification numbers 6076690 and 6076560; Nilges and Caldwell, 2012) were not used because of the level of effort, and the uncertainties involved, in synthesizing observed streamflow data for missing periods and estimating reconstructed-natural streamflow data (see sections "Calculation of the Reconstructed-Natural Streamflow Dataset" and "Potential Uses and Limitations of the Model").

The precipitation-runoff model simulates natural streamflow conditions in the Smith River watershed. The effects of diversions, reservoir regulation, and other water-resources development were not simulated in the model. Spatial and temporal data for diversions, reservoir regulation, and other water-resources development were not compiled for this study. The simulated-natural data were compared to reconstructednatural data to calibrate and evaluate the model.

\section{Calculation of the Observed Streamflow Dataset}

A complete set of observed daily streamflows was necessary to evaluate water-budget components for the study period (water years 1996-2008) and to calculate data for the model calibration (water years 2002-2007) and evaluation (water year 1996-2001) periods. These observed data include both measured streamflows from the USGS streamflow-gaging station (station identification number 06077500) Smith River near Eden, Montana (fig. 1, table 3), and synthesized flows. This was accomplished by a 3 -step process: (1) obtaining measured daily mean streamflow data from the USGS streamflowgaging station, (2) synthesizing monthly mean streamflow data for periods when measured streamflow data were not available, and (3) by using synthesized monthly streamflows to synthesize daily mean streamflow data for periods when measured streamflow data were not available.

Table 3. Information for selected streamflow gaging stations in and near the Smith River Basin, Montana (U.S. Geological Survey, 2012a).

\begin{tabular}{clcc}
\hline $\begin{array}{c}\text { Station } \\
\text { number }\end{array}$ & \multicolumn{1}{c}{ Station name } & $\begin{array}{c}\text { Drainage area } \\
\text { (square miles) }\end{array}$ & \multicolumn{1}{c}{ Period of record (through 2012) } \\
\hline 06077200 & Smith River below Eagle Creek near Fort Logan, Montana & 1,088 & $1996-2012$ \\
06077500 & Smith River near Eden, Montana & 1,594 & $1951-69,2006-10$ (seasonal records only) 2010-12 \\
06120500 & Musselshell River at Harlowton, Montana & 1,125 & $1907-29,1930-33,1934-2012$ \\
\hline
\end{tabular}


To calculate the observed-streamflow dataset (fig. 4), daily mean streamflow data at the USGS streamflow-gaging station (station identification number 06077500) Smith River near Eden, Montana, were obtained from the USGS National Water Information System (U.S. Geological Survey, 2012a) by using the Downsizer (Ward-Garrison and others, 2009). During the study period (water years 1996-2008) these daily data were available for March 1-September 30, 2006, March 1September 30, 2007, and March 1-September 30, 2008.

Then, monthly mean streamflows (referred to herein as monthly streamflows) for periods of missing records were synthesized by using the Maintenance of Variance Extension, Type 1 (MOVE.1) curve-fitting procedure described by Hirsch (1982) and Alley and Burns (1983) by using methods similar to those described in Chase (2013). Data from nearby USGS streamflow-gaging stations (station identification numbers 06120500 and 06077200; table 3) Musselshell River at Harlowton, Montana, and Smith River below Eagle Creek near Fort Logan, Montana, respectively, were used in the MOVE.1 analyses.

Finally, the synthesized monthly streamflows were used to synthesize daily mean streamflows by using methods similar to those described in Chase (2013). These synthesized daily mean streamflows and the measured daily mean streamflows herein are referred to as observed daily streamflows.

\section{Calculation of the Reconstructed-Natural Streamflow Dataset}

For the USGS streamflow-gaging station (station identification number 06077500) Smith River near Eden, Montana, reconstructed-natural streamflows (fig. 4) were calculated by adding agricultural depletions data from Reclamation (appendix; Clayton Jordan, U.S. Department of the Interior Bureau of Reclamation, written commun., 2011; U.S. Department of the Interior Bureau of Reclamation, 2012; U.S. Department of the Interior Bureau of Reclamation, 2005) to the observed streamflows. Reconstructed-natural streamflows represent estimates of streamflows during water years 1996-2007 assuming no agricultural water-resources development in the watershed. The reconstructed-natural daily streamflows were only calculated through 2007 because the Bureau of Reclamation data used in the calculations were only available through 2007.

Agricultural water-resources development includes diversions, on-farm and conveyance losses, and crop irrigation requirements. The agricultural depletions data also include effects of irrigation return flows. Effects of reservoir regulation were not included in the agricultural depletions data.

The Bureau of Reclamation developed monthly estimates of agricultural depletions (in Kilo acre-feet) for the Missouri River basin, including the Smith River watershed, for

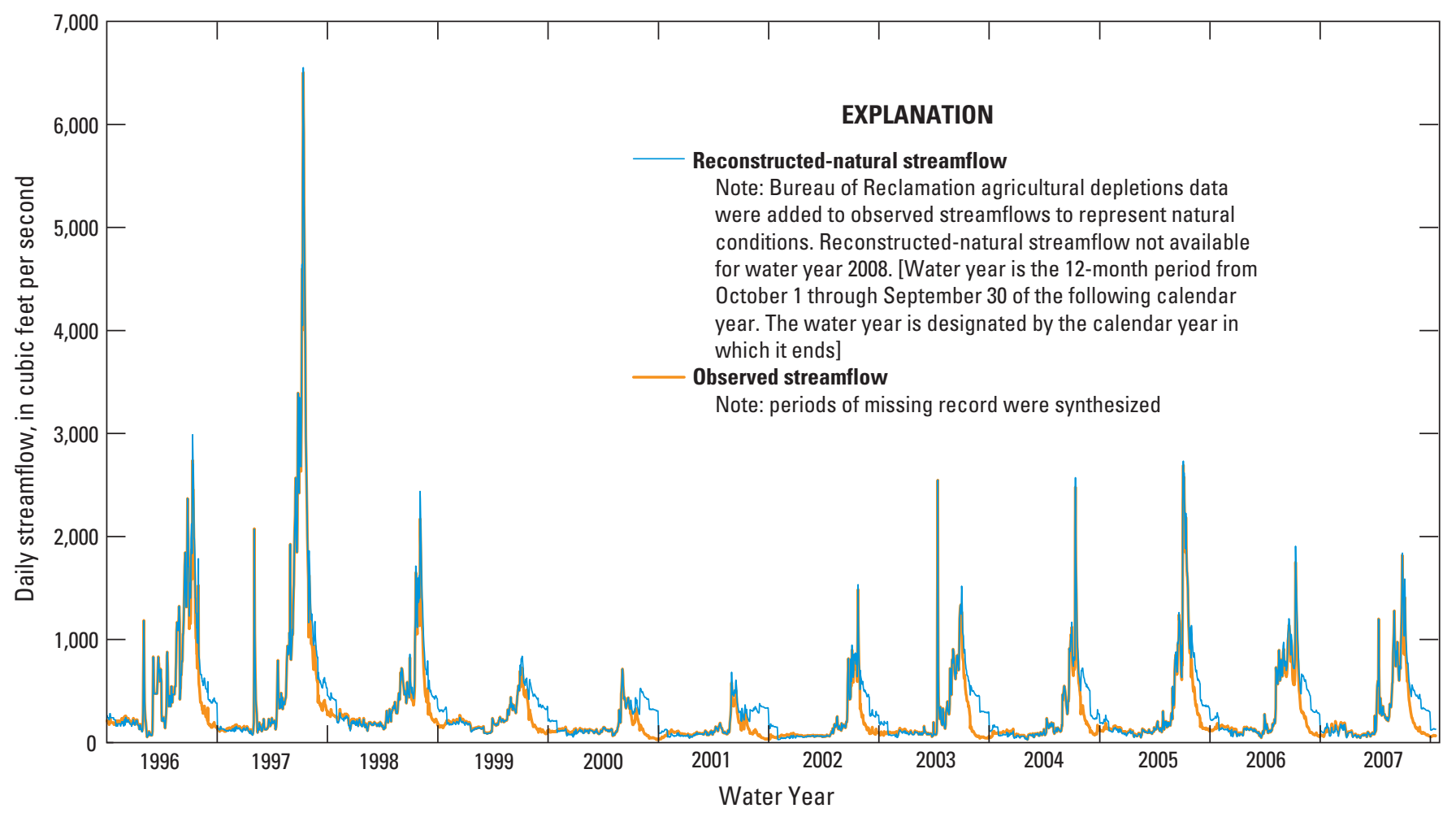

Figure 4. Reconstructed-natural and observed daily mean streamflow for U.S. Geological Survey streamflow-gaging station (station identification number 06077500) Smith River near Eden, Montana. 
water years 1929-2007, and supplied the USGS WyomingMontana Water Science Center with the agricultural depletions for the Smith River watershed (appendix; Clayton Jordan, U.S. Department of the Interior Bureau of Reclamation, written commun., 2011; U.S. Department of the Interior Bureau of Reclamation, 2012; U.S. Department of the Interior Bureau of Reclamation, 2005). The term "depletion" refers to changes to natural streamflows that result from water-resources development. In almost all cases, water-resources development results in net decreases in streamflow over periods of one to multiple years. Some agricultural water-resources development (for example irrigation operations), however, can result in decreases in streamflow (relative to natural conditions) during some seasons and increases in streamflow during other seasons. Thus, the term "depletion," as used by Reclamation (U.S. Department of the Interior Bureau of Reclamation, 2012; U.S. Department of the Interior Bureau of Reclamation, 2005) and in this report, does not imply a decrease in streamflow, especially on a seasonal basis. Positive depletions indicate decreases in streamflow relative to natural conditions, and negative depletions indicate increases in streamflow relative to natural conditions (Chase, 2013).

The historic agricultural depletions determined by Reclamation (U.S. Department of the Interior Bureau of Reclamation, 2005) included estimates of diversions, on-farm and conveyance losses, and crop irrigation requirements. Those estimates were based on climatological records, irrigated area, and irrigation methods for each year. Reclamation also calculated municipal depletions, but the municipal depletions for the Smith River watershed were less than 0.1 percent of the agricultural depletions; therefore, only the agricultural depletions were used in this study. The monthly depletions were distributed to daily depletions assuming a constant value for each day of each month. Depletions from reservoir operations were not determined by Reclamation for the Smith River watershed.

The uncertainties or confidence intervals associated with the depletions estimates for the Smith River watershed are unavailable and were assumed to be plus or minus 25 percent for this study. Reclamation calculated the depletions to assist the United States Army Corps of Engineers with determining unregulated (or natural) flows in the main stem Missouri River. The drainage area of the Smith River watershed is less than 0.4 percent of the drainage area of the Missouri River watershed included in Reclamation (2012). Because the depletion estimates were calculated to estimate unregulated flows on the main-stem Missouri River, it is unclear how well they represent depletions for rivers in smaller watersheds such as the Smith River watershed. Depletion calculation inputs included estimates for number of irrigated acres in each HUC, type of irrigation category (furrow, waterspreader, sprinkler, or other method), length of irrigation season, type of crop, climate (monthly mean temperature and total monthly precipitation), crop irrigation and diversion requirements, return flow distribution patterns, and depletions because of groundwater irrigation. Masoner and others (2003) compared irrigation water uses calculated by two different methods and calculated differences of 10-200 percent. If each of the Reclamation depletion calculation inputs contained uncertainties that lead to errors of 5 percent in the resulting depletion calculations, and the uncertainty values were additive, the uncertainty in the depletion calculation could be as high as 40 percent. In addition, the Reclamation depletions data do not include effects of reservoir regulation on streamflows. Reservoir operations could result in augmentation of low flows and dampening of high flows (Caldwell and EddyMiller, 2013). Because of the uncertainties in the Reclamation depletion estimates, and the exclusion of reservoir operations from the depletion estimates, an uncertainty of plus or minus 25 percent was chosen for calibrating and evaluating the Smith River model. This plus or minus 25 percent is lower than the highest uncertainties based on Masoner and others (2003) and lower than the 40 percent uncertainty based on adding 5 percent for each of the depletion calculation inputs, and so it is slightly more conservative for describing how well the model simulated natural streamflows (a higher uncertainty would lead to a wider target range for comparison with simulated streamflows). The uncertainties in the reconstructed-natural flows could be higher or lower, but plus or minus 25 percent was used for comparing reconstructednatural with simulated-natural in figures and tables herein. Further evaluation of stream diversions, reservoir regulation, and other water-resource development in the Smith River watershed likely would help quantify the uncertainty of the depletion values.

\section{Solar Radiation and Potential Evapotranspiration}

Observed mean monthly solar radiation (SR) and potential evapotranspiration (PE) data were used for model calibration and assessment. For the Smith River watershed, SR and PE calibration data were derived by following procedures developed by Hay and others (2006). Mean monthly SR values (12 values, 1 for each month, for the entire Smith River watershed) were interpolated from regression analysis of data for calendar years 1961-90 from a nationwide climate network of NRCS SNOTEL stations and NOAA National Weather Service (NWS) climate stations (Hay and others, 2006). Mean monthly PE values (12 values, 1 for each month, for the entire Smith River watershed) were calculated for 1956-70 from the free-water evaporation atlas of Farnsworth and others (1982). These SR and PE datasets were consistent with other PRMS modeling efforts across the United States (Hay and others, 2006; Chase, 2011).

\section{Model Calibration Approach}

A split-sample evaluation, similar to that used by Hay and others (2006), was used for calibration and evaluation of the model, as described on page 14 in Chase (2011). The model was calibrated for water years 2002-2007. Then, the 
model was evaluated for water years 1996-2001. An automated calibration computer program called Let Us Calibrate (LUCA; Hay and Umemoto, 2006) was used for calibration by adjusting parameter values until the simulated values of calibration targets matched the observed values as closely as possible (as described on page 14, Chase, 2011). Calibration involved several steps. In each calibration step, simulated and observed values for one of the calibration targets (table 4) were compared, and values of the parameters associated with that calibration target were adjusted to obtain the best agreement between simulated and observed calibration target values.

Multiple targets were used for calibration. Because SR and PE affect the overall water balance in the watershed, values of parameters associated with SR and PE (table 4) were adjusted first. Then, values of parameters associated with mean annual streamflow and mean monthly streamflow (also related to the overall water balance) were adjusted. Because of uncertainties related to the depletions data (discussed in the section "Calculation of the Reconstructed-Natural Streamflow Dataset"), a range (plus or minus 25 percent) of streamflow values was used for calibration instead of a single value for each month or year. After the water-balance parameters were adjusted, the parameters associated with daily mean streamflow were adjusted, again by using a range (plus or minus 25 percent) of streamflow values for each day instead of a single value for each day. The parameters listed in table 4 for each calibration target were determined from a single parameter sensitivity analysis conducted for a snowmelt-dominated watershed by using Monte Carlo techniques (Hay, Leavesley, Clark, and others, 2006).

\section{Model Calibration Results}

At the USGS streamflow-gaging station (station identification number 06077500) Smith River near Eden, Montana, simulated-natural mean annual and mean monthly flows generally were the same or higher than the reconstructednatural streamflows during the calibration period (water years 2002-2007), whereas they were lower during the evaluation period (water years 1996-2001). Both simulated-natural mean annual streamflow and simulated-natural mean April-July streamflow values fell within the target-value range for the calibration period, and were 11-14 percent lower than the bottom of the target range during the evaluation period (table 5). Simulated mean monthly streamflow values fell close to (less than 15 percent above the top or below the bottom of the target-value range) or within the target-value range during the calibration period, except for October, when values were overestimated by 56 percent, and March, when values were underestimated by 20 percent during the calibration period (table 5). For all months except October, June, and September, mean monthly streamflow values were underestimated during the evaluation period by 6 to 60 percent below the bottom of the target-value range (table 5).
Annual mean simulated-natural streamflow values were within the target-value range for the calibration period, and were 0 to 33 percent lower than the bottom of the target-value range for the evaluation period (table 6). The shape of the annual hydrograph for the simulated-natural daily streamflow values generally matched the shape of the hydrograph for the reconstructed-natural values for most of the calibration period (fig. $5 A$ ), which indicates that interflow and groundwater processes likely were well-represented within the model. In water year 2003, an early observed March streamflow peak in the reconstructed-natural streamflow, that could have been caused by snowmelt on frozen ground or ice jams within the stream channel, was not simulated by the model. Higher reconstructed-natural streamflows in May and June of that same year also were underestimated. During the evaluation period, the highest (or peak) simulated-natural daily streamflow values for each year were underestimated in water years 1996-1998 and overestimated in water year 1999 (fig. 5B). The simulated-natural daily peak streamflow occurred later than the reconstructed-natural streamflow in water years 2000 and 2001.

The Nash-Sutcliffe efficiency (NS) statistic (Moriasi and others, 2007) was used to evaluate how well the model simulated daily natural streamflow as compared to the reconstructed-natural streamflow (plus or minus the 25 percent target-value range). The NS is a normalized statistic that provides a measure of how well simulated values match measured datasets. NS values range from negative infinity to 1 . Values of 0 or less indicate that the average value of all the reconstructednatural streamflow data is a better predictor than simulated daily natural streamflow. A value of 0 indicates the simulated daily natural streamflow is as good as using the average value of all the reconstructed-natural streamflow data, and a value of 1 indicates a perfect fit between reconstructed-natural streamflow and simulated daily natural streamflow. Moriasi and others (2007) suggest that a NS of greater than 0.50 is satisfactory for streamflows simulated by using models such as PRMS. NS statistics for the calibration (water years 2002-2007) and evaluation (water years 1996-2001) periods were 0.92 and 0.87 , respectively, by using the plus or minus 25 percent target-value range around the reconstructed-natural streamflow values. NS statistics for the calibration and evaluation periods were 0.87 and 0.69 , respectively, by using the reconstructed-natural streamflow values without the target-value range.

The underestimation of streamflow during the evaluation period could be because of climatological differences between the calibration and evaluation periods. Mean annual reconstructed-natural streamflow was lower during the calibration period $\left(309 \mathrm{ft}^{3} / \mathrm{s}\right)$ than for the evaluation period $\left(400 \mathrm{ft}^{3} / \mathrm{s}\right.$, table 5); and the simulated mean annual temperature during the calibration period $\left(41^{\circ} \mathrm{F}\right.$, or $\left.5^{\circ} \mathrm{C}\right)$ was higher than for the evaluation period $\left(40^{\circ} \mathrm{F}\right.$, or $\left.4.4^{\circ} \mathrm{C}\right)$. Therefore, the model was calibrated during a drier, warmer period, which could have resulted in underestimated flows during the wetter, cooler evaluation period. Model uncertainties are further discussed in the section "Potential Uses and Limitations of the Model". 


\section{A Precipitation-Runoff Model for Simulating Natural Streamflow Conditions in the Smith River Watershed, Montana}

Table 4. Calibration targets and parameters used in the Let Us Calibrate (LUCA) calibration procedure for the precipitation-runoff model.

[Table modified from Hay, Leavesley, Clark, and others (2006). LUCA, Let Us Calibrate; SR, solar radiation; PE, potential evapotranspiration; NRMSE, normalized root mean square error; HRU, hydrologic response unit]

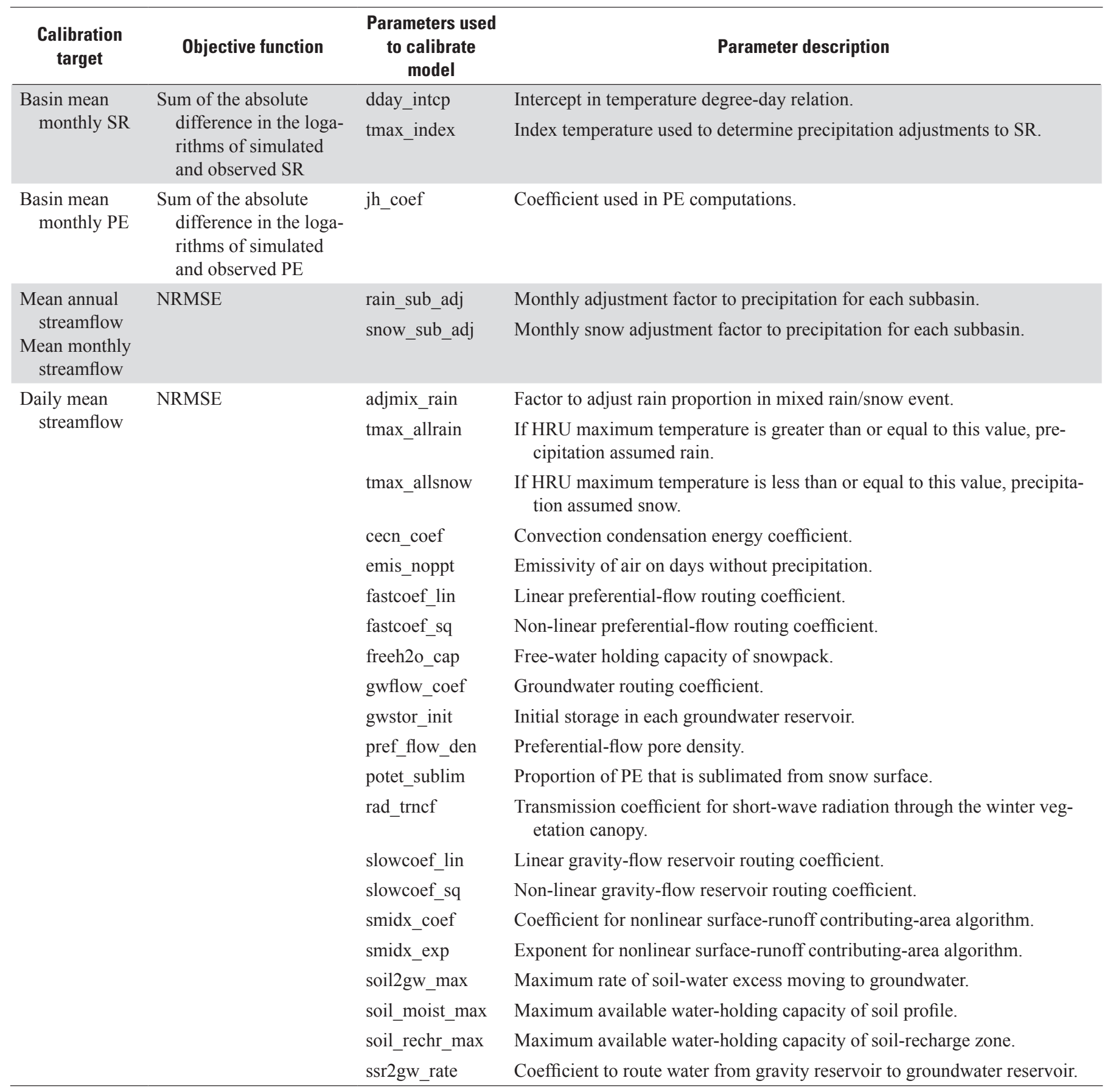


Table 5. Simulated-natural and reconstructed-natural mean monthly, mean annual, and mean April-July streamflow for the calibration and evaluation periods for U.S. Geological Survey streamflow-gaging station (station identification number 06077500) Smith River near Eden, Montana.

[The reconstructed streamflow data for this gage were calculated by adding Bureau of Reclamation depletions data (Clayton Jordan, Civil Engineer, Bureau of Reclamation, written commun., 2011) to the reconstructed-natural streamflow data ${ }^{1}$. If $A>D, E=(A-D) / D$, if $A<C$, $\mathrm{E}=(\mathrm{A}-\mathrm{C}) / \mathrm{C}$, if $\mathrm{C}<\mathrm{A}<\mathrm{D}, \mathrm{E}=0$. Negative percent errors indicate simulations underestimated; positive percent errors indicate simulations overestimated. $\mathrm{ft}^{3} / \mathrm{s}$, cubic feet per second; \pm , plus or minus; Water year, 12-month period from October 1 through September 30 of the following calendar year. The water year is designated by the calendar year in which it ends]

\begin{tabular}{|c|c|c|c|c|c|}
\hline \multirow{3}{*}{ Month } & \multicolumn{5}{|c|}{ Streamflow } \\
\hline & \multirow{2}{*}{$\begin{array}{c}\text { A } \\
\text { Mean } \\
\text { simulated- } \\
\text { natural } \\
\left(\mathrm{ft}^{3} / \mathbf{s}\right)\end{array}$} & \multirow{2}{*}{$\begin{array}{c}\text { B } \\
\text { Mean } \\
\text { reconstructed- } \\
\text { natural } \\
\left(\mathrm{ft}^{3} / \mathrm{s}\right)\end{array}$} & \multicolumn{2}{|c|}{$\begin{array}{l}\text { Mean reconstructed-natural range } \\
\qquad( \pm 25 \text { percent })\left(\mathrm{ft}^{3} / \mathrm{s}\right)\end{array}$} & \multirow{2}{*}{$\begin{array}{c}\text { E } \\
\text { Error outside } \\
\text { of range } \\
\text { (percent) }\end{array}$} \\
\hline & & & $\begin{array}{c}\text { C } \\
\text { Bottom of range } \\
\left(\mathrm{ft}^{3} / \mathrm{s}\right)\end{array}$ & $\begin{array}{c}\text { D } \\
\text { Top of range } \\
\left(\mathrm{ft}^{3} / \mathrm{s}\right)\end{array}$ & \\
\hline \multicolumn{6}{|c|}{ Calibration period: water years 2002-2007 } \\
\hline \multicolumn{6}{|c|}{ Mean monthly } \\
\hline October & 171 & 88 & 66 & 110 & 56 \\
\hline November & 127 & 90 & 68 & 113 & 13 \\
\hline December & 83 & 77 & 58 & 97 & 0 \\
\hline January & 70 & 82 & 62 & 103 & 0 \\
\hline February & 73 & 85 & 64 & 106 & 0 \\
\hline March & 125 & 209 & 157 & 261 & -20 \\
\hline April & 339 & 297 & 223 & 372 & 0 \\
\hline May & 666 & 743 & 557 & 929 & 0 \\
\hline June & 876 & 1,010 & 758 & 1,263 & 0 \\
\hline July & 372 & 559 & 419 & 698 & -11 \\
\hline August & 229 & 297 & 223 & 372 & 0 \\
\hline September & 192 & 171 & 128 & 214 & 0 \\
\hline \multicolumn{6}{|c|}{ Mean annual } \\
\hline Mean & 277 & 309 & 232 & 386 & 0 \\
\hline \multicolumn{6}{|c|}{ Mean for April-July } \\
\hline Mean & 563 & 652 & 489 & 815 & 0 \\
\hline \multicolumn{6}{|c|}{ Evaluation period: water years 1996-2001 } \\
\hline \multicolumn{6}{|c|}{ Mean monthly } \\
\hline October & 143 & 133 & 100 & 166 & 0 \\
\hline November & 103 & 145 & 109 & 181 & -6 \\
\hline December & 79 & 137 & 103 & 172 & -23 \\
\hline January & 62 & 173 & 130 & 216 & -52 \\
\hline February & 60 & 203 & 152 & 254 & -60 \\
\hline March & 122 & 225 & 169 & 281 & -28 \\
\hline April & 219 & 389 & 292 & 486 & -25 \\
\hline May & 510 & 836 & 627 & 1,045 & -19 \\
\hline June & 931 & 1,231 & 923 & 1,539 & 0 \\
\hline July & 457 & 700 & 525 & 875 & -13 \\
\hline August & 251 & 406 & 305 & 508 & -18 \\
\hline September & 169 & 224 & 168 & 281 & 0 \\
\hline \multicolumn{6}{|c|}{ Mean annual } \\
\hline Mean & 259 & 400 & 300 & 500 & -14 \\
\hline \multicolumn{6}{|c|}{ Mean for April-July } \\
\hline Mean & 529 & 789 & 592 & 986 & -11 \\
\hline
\end{tabular}

${ }^{1}$ Observed streamflow is defined as streamflow for current conditions, including the effects of reservoir regulation, diversions, and other water-resources development throughout the watershed. 
Table 6. Simulated-natural and reconstructed-natural annual mean streamflow for the calibration and evaluation periods for U.S. Geological Survey streamflow-gaging station (station identification number 06077500) Smith River near Eden, Montana.

[The reconstructed-natural streamflow data for this gage were calculated by adding Bureau of Reclamation depletions data (Clayton Jordan, Civil Engineer, Bureau of Reclamation, written commun., 2011) to the observed streamflow data ${ }^{1}$. If A $>D$, $\mathrm{E}=(\mathrm{A}-\mathrm{D}) / \mathrm{D}$, if $\mathrm{A}<\mathrm{C}, \mathrm{E}=(\mathrm{A}-\mathrm{C}) / \mathrm{C}$, if $\mathrm{C}<\mathrm{A}<\mathrm{D}, \mathrm{E}=0$. Negative percent errors indicate simulations underestimated; positive percent errors indicate simulations overestimated. $\mathrm{ft}^{3} / \mathrm{s}$, cubic feet per second; \pm , plus or minus; Water year, 12 -month period from October 1 through September 30 of the following calendar year. The water year is designated by the calendar year in which it ends]

\begin{tabular}{|c|c|c|c|c|c|}
\hline \multirow{3}{*}{ Water Year } & \multicolumn{5}{|c|}{ Annual mean streamflow } \\
\hline & \multirow{2}{*}{$\begin{array}{c}\text { A } \\
\text { Simulated- } \\
\text { natural } \\
\left(\mathrm{ft}^{3} / \mathrm{s}\right)\end{array}$} & \multirow{2}{*}{$\begin{array}{c}\text { B } \\
\text { Reconstructed- } \\
\text { natural } \\
\left(\mathrm{ft}^{3} / \mathrm{s}\right)\end{array}$} & \multicolumn{2}{|c|}{$\begin{array}{l}\text { Reconstructed-natural range } \\
\quad( \pm 25 \text { percent })\left(\mathrm{ft}^{3} / \mathrm{s}\right)\end{array}$} & \multirow{2}{*}{$\begin{array}{c}\text { E } \\
\text { Error outside } \\
\text { of range } \\
\text { (percent) }\end{array}$} \\
\hline & & & $\begin{array}{c}\text { C } \\
\text { Bottom of range } \\
\left(\mathrm{ft}^{3} / \mathrm{s}\right)\end{array}$ & $\begin{array}{c}\text { D } \\
\text { Top of range } \\
\left(\mathrm{ft}^{3} / \mathrm{s}\right)\end{array}$ & \\
\hline \multicolumn{6}{|c|}{ Calibration period: water years 2002-2007 } \\
\hline 2002 & 184 & 217 & 162 & 271 & 0 \\
\hline 2003 & 237 & 314 & 236 & 393 & 0 \\
\hline 2004 & 297 & 271 & 203 & 339 & 0 \\
\hline 2005 & 306 & 386 & 290 & 483 & 0 \\
\hline 2006 & 328 & 341 & 256 & 427 & 0 \\
\hline 2007 & 311 & 331 & 248 & 414 & 0 \\
\hline \multicolumn{6}{|c|}{ Evaluation period: water years 1996-2001 } \\
\hline 1996 & 276 & 552 & 414 & 690 & -33 \\
\hline 1997 & 475 & 786 & 590 & 983 & -19 \\
\hline 1998 & 246 & 414 & 311 & 518 & -21 \\
\hline 1999 & 221 & 274 & 206 & 343 & 0 \\
\hline 2000 & 180 & 204 & 153 & 255 & 0 \\
\hline 2001 & 158 & 181 & 136 & 226 & 0 \\
\hline
\end{tabular}

${ }^{1}$ Observed streamflow is defined as streamflow for current conditions, including the effects of reservoir regulation, diversions, and other water-resources development throughout the watershed.

Calibrating the model to SR and PE improved the model representation of evapotranspiration processes. Simulated mean monthly SR values were lower (less than 30 percent) than observed values from November to February for both calibration and evaluation periods, and were lower than observed from April to July for the evaluation period (fig. $6 A$ ). Simulated $\mathrm{PE}$ values were equal to observed values for the calibration period except for during the month of January (difference of less than 0.01 inch per day [in/d]; fig. $6 B$ ). Simulated PE values for the evaluation period were lower than observed values for May through July (largest difference of less than 10 percent in July), which corresponded with the lower simulated SR values during those months. Simulated PE values for the evaluation period were slightly (less than $0.01 \mathrm{in} / \mathrm{d}$ ) higher than observed for August and September, which corresponded to higher SR values during those months (figs. $6 A$ and $6 B$ ). These differences between simulated and observed SR and PE values are similar to other PRMS studies (Chase, 2011; Dudley, 2008).

\section{Model Results for Simulated Natural Streamflow Conditions}

Various spatial and temporal components of the water budget for the Smith River watershed can be evaluated by using the model. For example, model results indicate that during the water year 1996-2008 study period, simulated mean annual precipitation across the Smith River watershed was 16 in., out of which 14 inches evaporated or transpired and 2 inches left the basin as streamflow (fig. 7). Model results also illustrate how the generalized annual water budget varies by year (fig. 8) and by month (fig. 9). During each year, water flowing into storage is about equal to water flowing out of storage, resulting in relatively small total changes in storage each year relative to the annual water budget (fig. 8). However, simulated month-to-month changes in storage are large relative to the monthly water budget (fig. 9; only water years 2002-2008 shown for clarity). Storage simulated in PRMS can occur in the groundwater, in pores in the soil, and in the 
A. Water years 2002-2007 (calibration period)

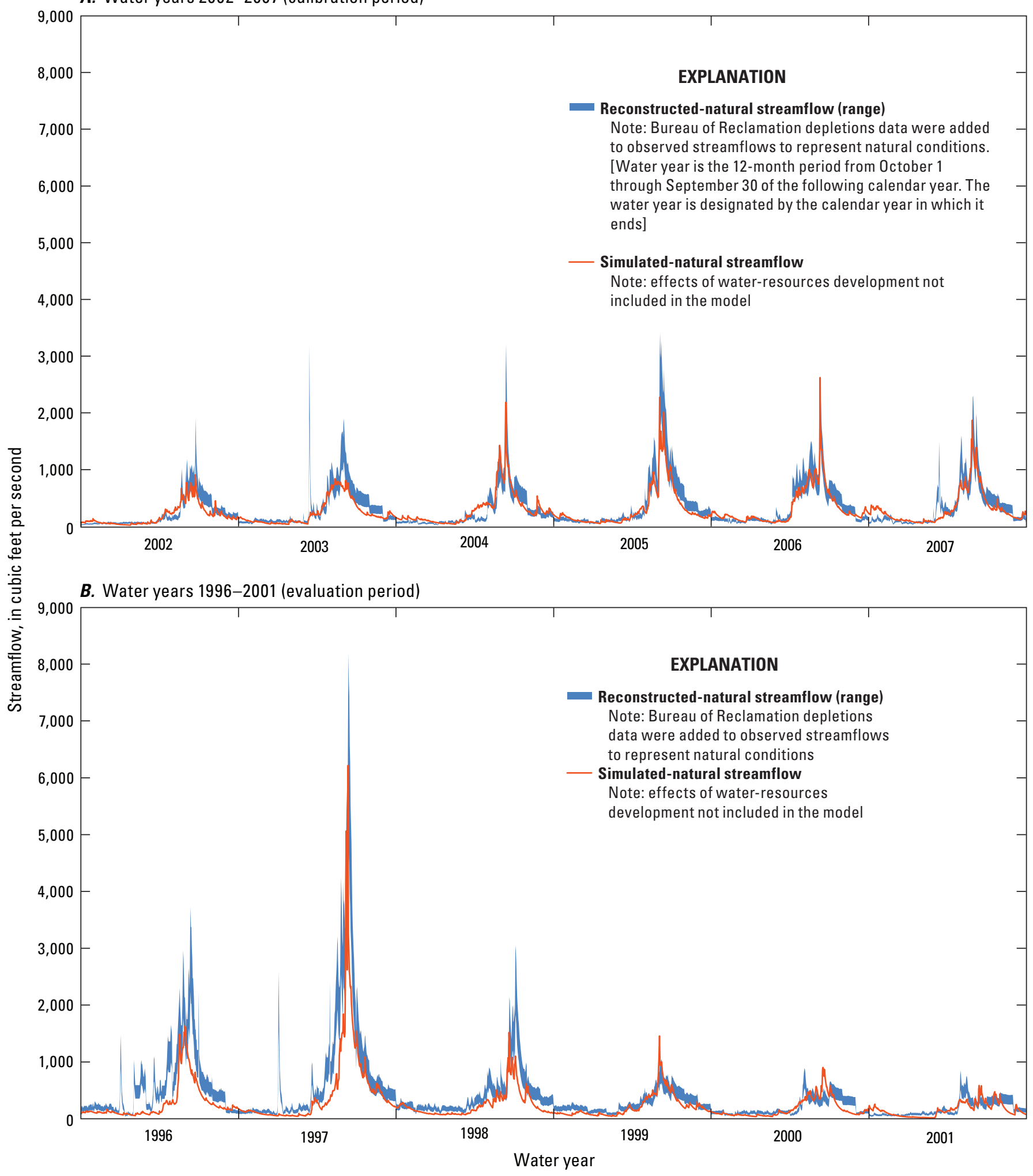

Figure 5. Simulated-natural and reconstructed-natural daily mean streamflow for U.S. Geological Survey streamflow-gaging station (station identification number 06077500) Smith River near Eden, Montana. A, Water years 2002-2007 (calibration period). B, Water years 1996-2001 (evaluation period). 
A. Mean monthly solar radiation

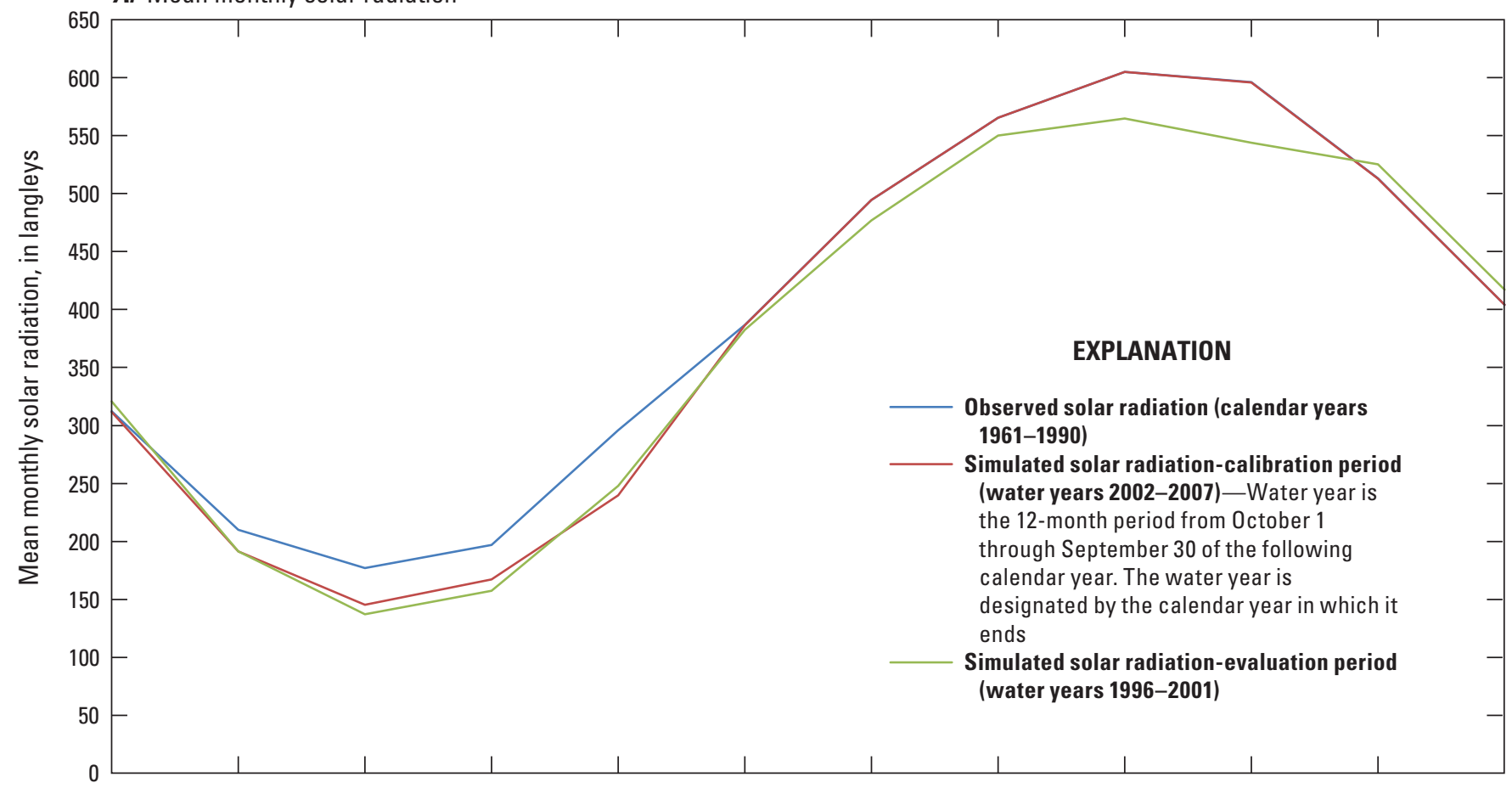

B. Mean monthly potential evapotranspiration

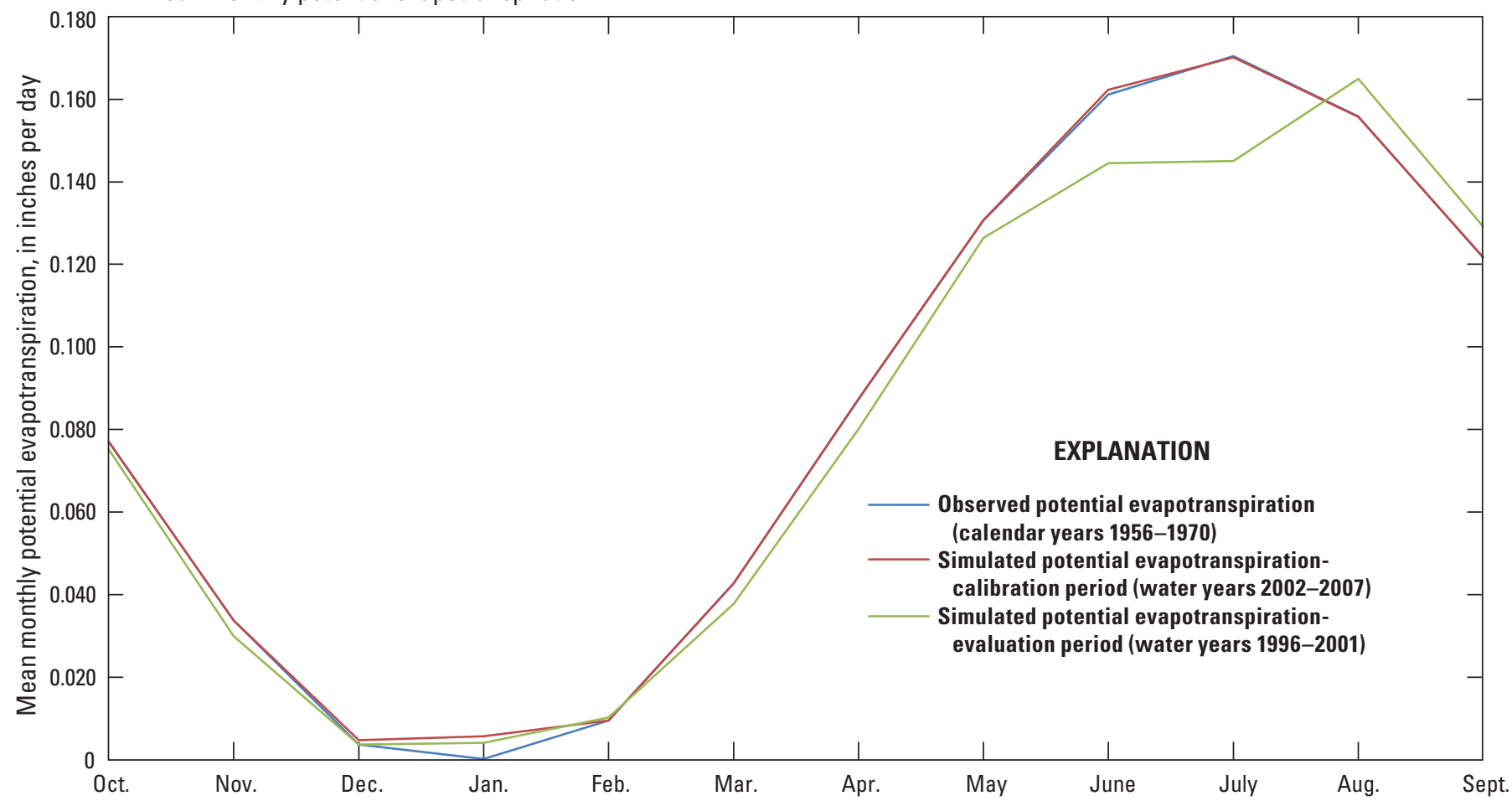

Figure 6. Simulated and observed climate variables for the Smith River watershed, Montana. $A$, Mean monthly solar radiation. $B$, Mean monthly potential evapotranspiration. 


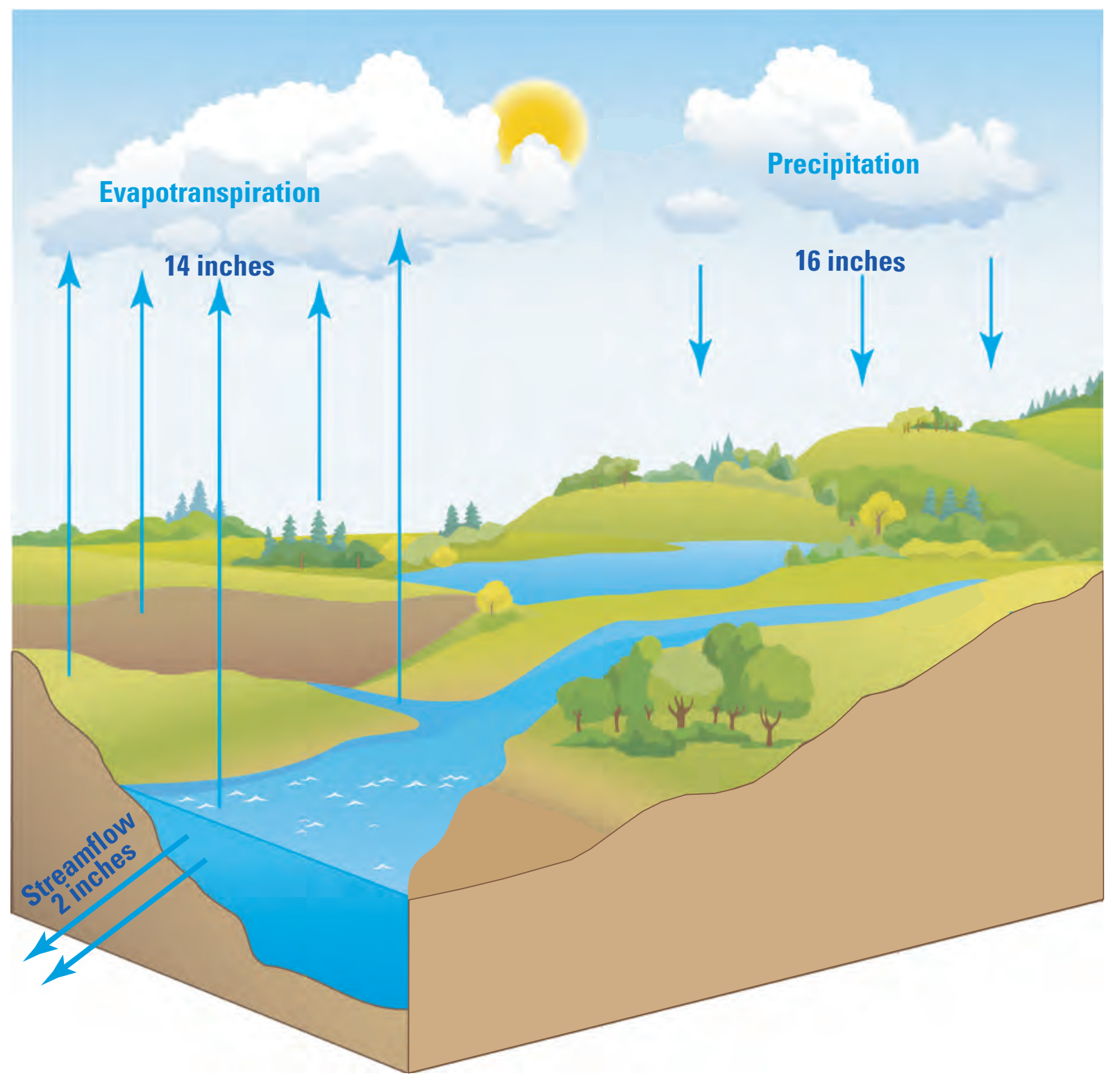

Figure 7. Simulated-natural average annual water budget for the Smith River watershed, water years 1996-2008. 


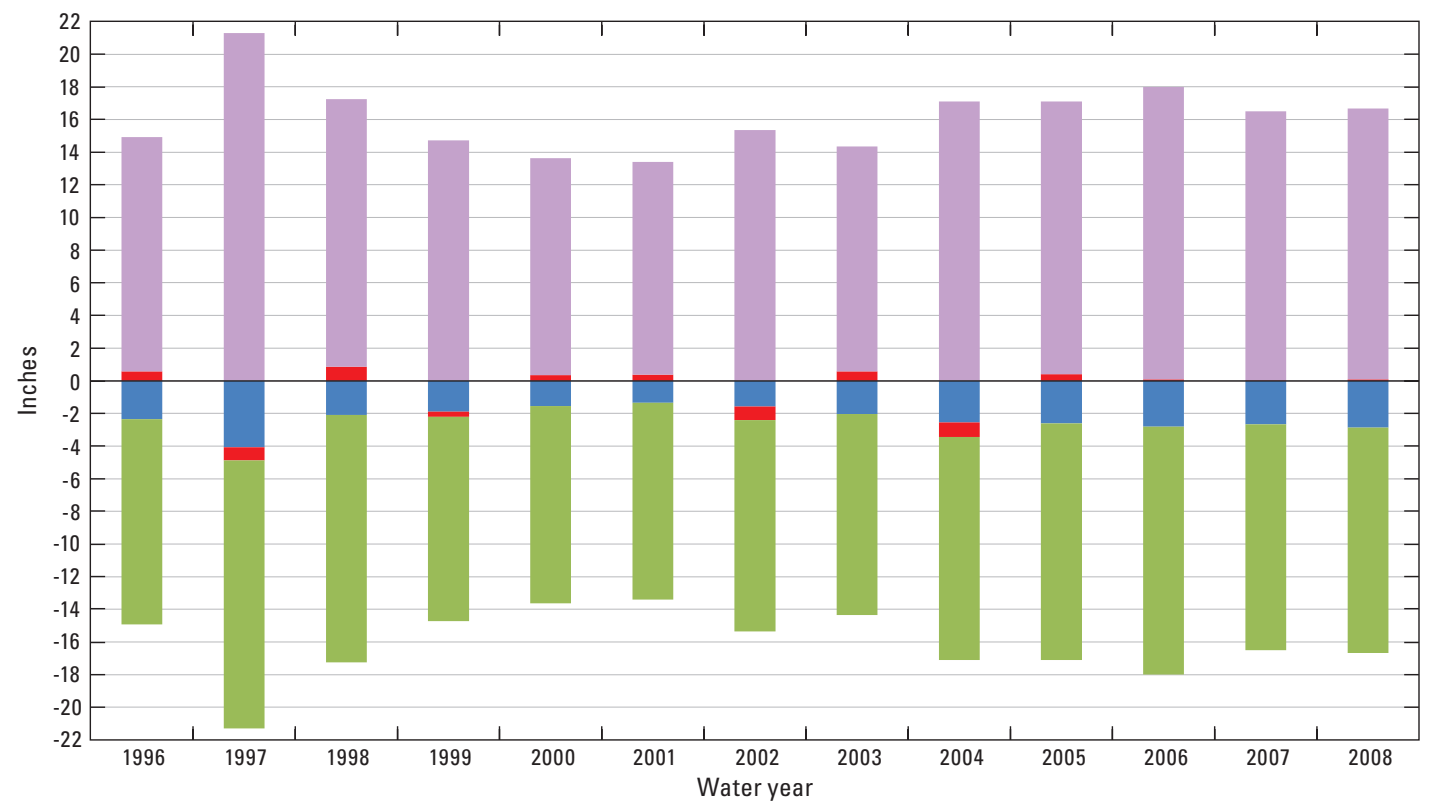

EXPLANATION

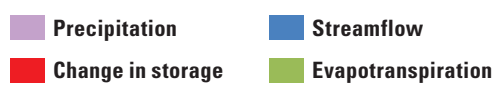

Figure 8. Simulated-natural annual water budget for the Smith River watershed, water years 1996-2008. [Water year is the 12-month period from October 1 through September 30 of the following calendar year. The water year is designated by the calendar year in which it ends]

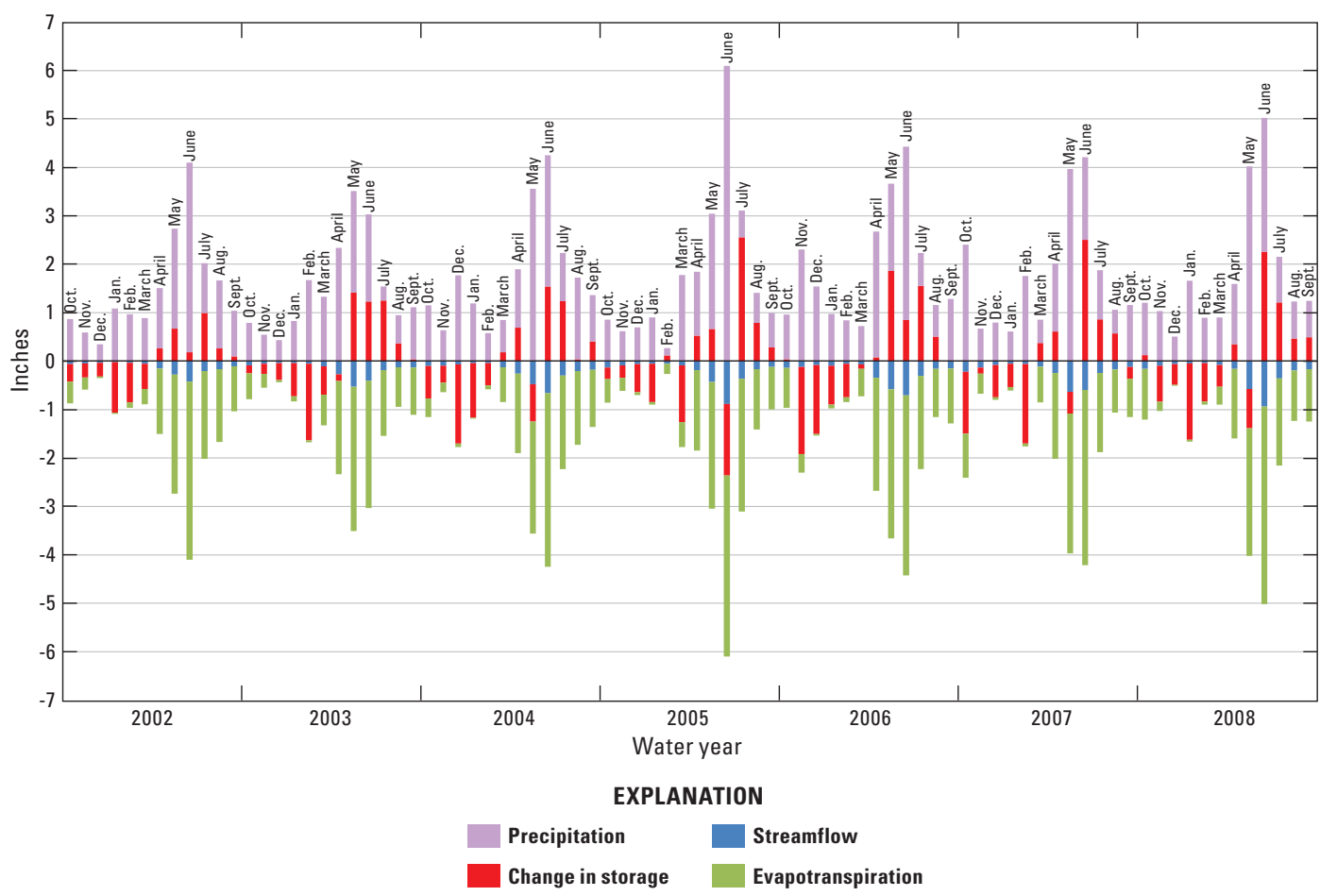

Figure 9. Simulated-natural monthly water budget for the Smith River watershed, water years 2002-2008. [Water year is the 12-month period from October 1 through September 30 of the following calendar year. The water year is designated by the calendar year in which it ends] 
snowpack. As discussed in the section "Streamflow," the model does not simulate effects of reservoir regulation in the watershed.

Per the model simulations, during most of the year, surface runoff rarely (less than 2 percent of the time during water years 2002-2008) makes up more than 10 percent of the total streamflow (fig. 10; only water years 2002-2008 shown for clarity). Subsurface flow (the combination of interflow and groundwater flow) makes up most of the total streamflow (99 or more percent of total streamflow for 71 percent of the time during water years 2002-2008). Similar distributions between surface runoff and subsurface flow have been documented in other PRMS simulations of snowmelt-dominated streamflow, in mountainous terrain in the Western United States (Mastin and Vaccaro, 2002; Koczot and others, 2005; Laenen and Risley, 1995), and in the rolling hills along the Atlantic coast (Dudley, 2008).

The model can be used to examine the contributions from various parts of the watershed relative to the total streamflow within the watershed. For example, the watershed above USGS streamflow-gaging station (station identification number 06077200) Smith River below Eagle Creek near Fort Logan, Montana, makes up 68 percent of the total drainage area above USGS streamflow-gaging station (station identification number 06077500) Smith River near Eden, Montana (fig. 11). Accordingly, the simulated-natural mean annual streamflow for water years 1996-2008 at U.S. Geological Survey streamflow-gaging station (station identification number 06077200) Smith River below Eagle Creek near Fort Logan, Montana is 189 cubic feet per second $\left(\mathrm{ft}^{3} / \mathrm{s}\right)$ or 69 percent of the simulated-natural mean annual streamflow at U.S. Geological Survey streamflow-gaging station (station identification number 06077500) Smith River near Eden, Montana (fig.11).

\section{Potential Uses and Limitations of the Model}

The model constructed for the Smith River watershed can be used to examine the general hydrologic framework of the Smith River watershed, including quantification of precipitation, evapotranspiration, and streamflow; partitioning of streamflow between surface runoff and subsurface flow; and quantifying contribution to streamflow from different parts of the watershed. The model can be further refined to simulate regulated (or observed) flows by adding algorithms to simulate reservoir operation, diversions, and return flows. Remotelysensed evapotranspiration values could provide further information for the refined model. That refined model could be used to estimate possible future streamflow scenarios, such as changes to irrigation practices or land use, or streamflow

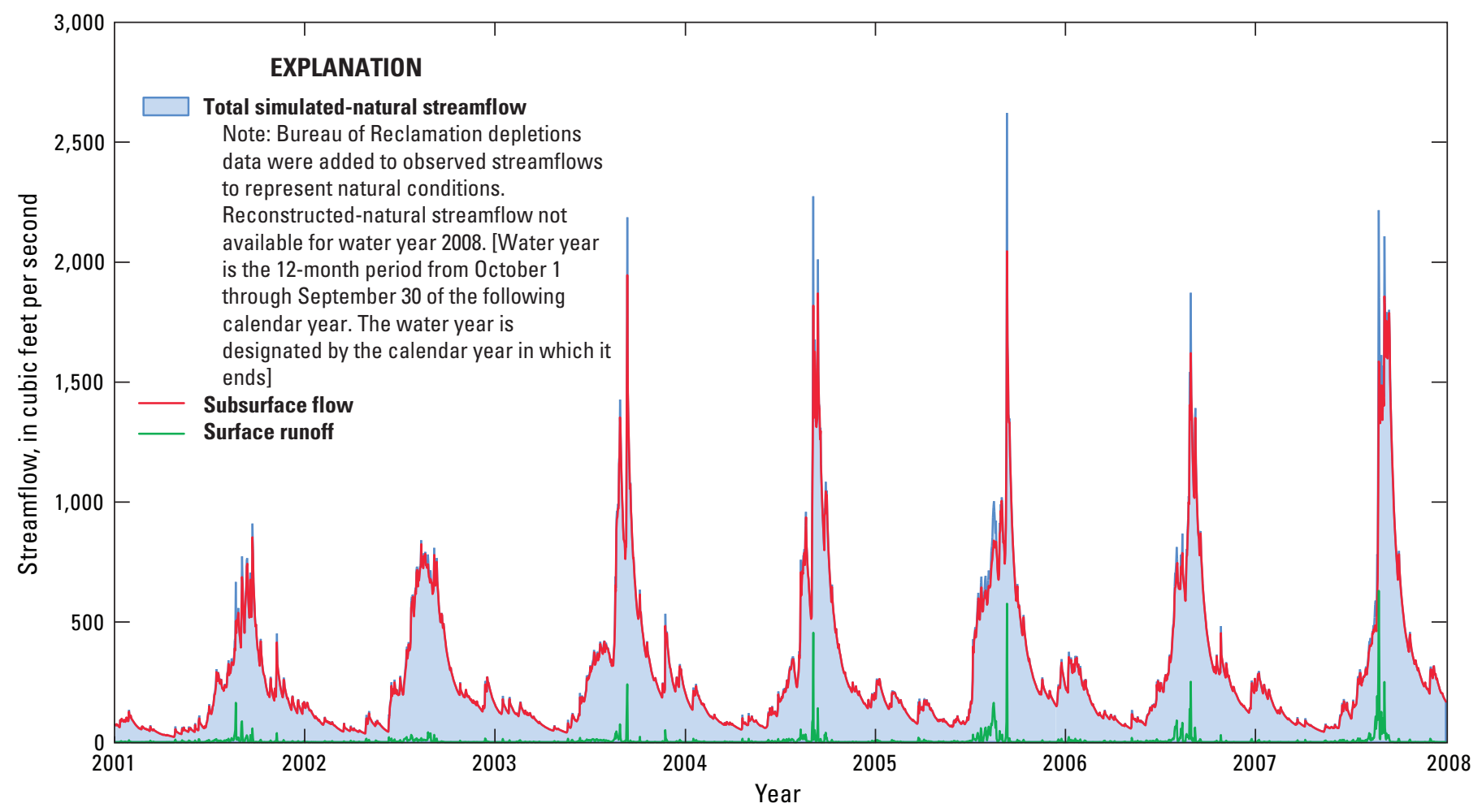

Figure 10. Partition of total simulated-natural streamflow into subsurface flow and surface runoff for the Smith River watershed, Montana, water years 2002-2008. 


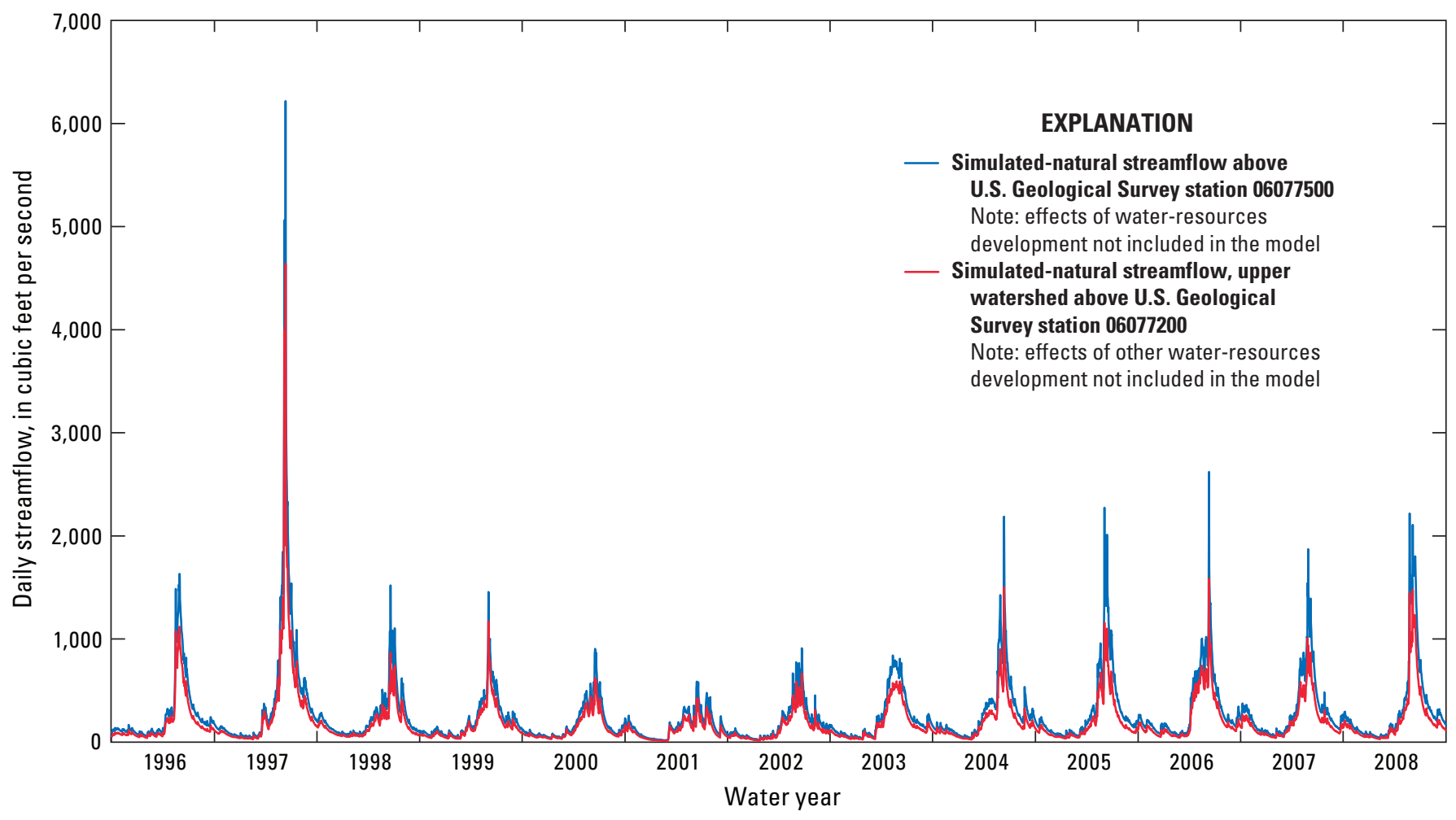

Figure 11. Simulated-natural streamflow for the Smith River watershed at Smith River at U.S. Geological Survey streamflow-gaging station (station identification number 06077500) Smith River near Eden, Montana, and at U.S. Geological Survey streamflow-gaging station (station identification number 06077200) Smith River below Eagle Creek near Fort Logan, Montana. [Water year is the 12-month period from October 1 through September 30 of the following calendar year. The water year is designated by the calendar year in which it ends]

responses to drought. The model also can be combined with a groundwater model to further investigate interactions between surface water and groundwater under changing land use and irrigation scenarios.

The model is a mathematical representation of the physical conditions and processes in the Smith River watershed. Potential uncertainties include uncertainties in the mathematical representation of the physical conditions and processes (model uncertainties); uncertainties in the precipitation, air temperature, streamflow, SR, and PE data (time-series data uncertainties); uncertainties in the distribution of the timeseries data to the HRUs (time-series data interpolation uncertainties); and uncertainties associated with the values of the model parameters (parameter uncertainties).

Unlike groundwater-flow models such as MODFLOW, or coupled groundwater and surface-water flow models such as GSFLOW, the PRMS model does not include partial differential equations that describe the movement of groundwater. Instead, the PRMS model represents groundwater flow by using empirical and simplified equations that do not consider the effect of local geology and surface-water interactions (Markstrom and others, 2008). For this study, interflow and groundwater-flow data were not used for model input, calibration, or evaluation. In addition, hydraulic properties of the aquifer or groundwater system were not quantified as part of this study.
The model was calibrated to daily mean and mean monthly reconstructed-natural streamflow at USGS streamflow-gaging station (station identification number 06077500) Smith River near Eden, Montana. The model was not calibrated to extremely high or low daily streamflow, nor was it created to simulate storm events (storm events can be better simulated with air temperature and precipitation data at hourly or minute intervals). Uncertainties associated with the Reclamation data used to calculate reconstructed-natural streamflow values for calibration are unknown; further evaluation of site-specific diversion and reservoir regulation data might help quantify these uncertainties. The parameter values for soils, land cover, and forest type do not reflect changes caused by periodic forest fires or land use practices.

\section{Summary}

This report documents the construction of a precipitationrunoff model for simulating natural streamflow in the Smith River watershed, Montana. This Precipitation Runoff Modeling System model, constructed in cooperation with the Meagher County Conservation District, can be used to examine the general hydrologic framework of the Smith River watershed, including quantification of precipitation, evapotranspiration, 
and streamflow; partitioning of streamflow between surface runoff and subsurface flow; and quantifying contribution to streamflow from different parts of the watershed.

Five input files were used to run, calibrate and evaluate the model. The parameter input file contains values of parameters that describe the basin topography, the stream network, and the hydrologic characteristics of the basin soils and vegetation. Three time-series input data files are required to run the model; one data file contains values of daily total precipitation for the Smith River watershed, and the other two data files contain values of maximum and minimum daily air temperature for the Smith River watershed. A fifth input file containing reconstructed-natural daily mean streamflow at USGS streamflow-gaging stations along the Smith River was used for model calibration and evaluation.

The model was calibrated for water years 2002-2007 and evaluated for water years 1996-2001. An automated calibration computer program, called Let Us Calibrate (LUCA), was used for calibration by adjusting parameter values until the simulated values of calibration targets matched the observed values as closely as possible. During the calibration and evaluation periods, simulated-natural flow values were compared to reconstructed-natural streamflow data. These reconstructednatural streamflow data were calculated by adding Bureau of Reclamation's agricultural depletions data to the observed streamflows. Reconstructed-natural streamflows represent estimates of streamflows during water years 1996-2007 assuming there was no agricultural water-resources development in the watershed. Additional calibration targets included basin mean monthly solar radiation and potential evapotranspiration.

The model estimated the hydrologic processes occurring in the Smith River watershed. Both simulated-natural mean annual streamflow and simulated-natural mean April-July streamflow values fell within the target-value range values for the calibration period (water years 2002-2007), and were 11-14 percent lower than the bottom of the target-value range for the evaluation period (water years 1996-2001). Simulated mean monthly streamflow values fell close to (less than 15 percent above the top or below the bottom of the target range) or within the target-value range during the calibration period, except for October, when values were overestimated by 56 percent, and March, when values were underestimated by 20 percent. For all months except October, June, and September, mean monthly streamflow values were underestimated during the evaluation period by 6 to 60 percent below the bottom of the target-value range.

Annual mean simulated-natural streamflow values were within the target-value range for the calibration period and were 0 to 33 percent lower than the bottom of the targetvalue range for the evaluation period. The shape of the annual hydrographs for the simulated-natural daily streamflow values matched the shape of the hydrographs for the reconstructednatural values fairly well for most of the calibration period. During the evaluation period simulated-natural daily peak streamflow values were underestimated in water years
1996-1998 and overestimated in water year 1999. NS statistics for the calibration (water years 2002-2007) and evaluation (water years 1996-2001) periods were 0.92 and 0.87, respectively, by using the plus or minus 25 percent target-value range around the reconstructed-natural streamflow values.

The precipitation-runoff model enabled a detailed evaluation of the various components of the water budget within the Smith River watershed. During the water year 1996-2008 study period, simulated mean annual precipitation across the Smith River watershed was 16 inches, out of which 14 inches evaporated or transpired and 2 inches left the basin as streamflow. Per the model simulations, during most of the year, surface runoff rarely (less than 2 percent of the time during water years 2002-2008) makes up more than 10 percent of the total streamflow. Subsurface flow (the combination of interflow and groundwater flow) makes up most of the total streamflow (99 or more percent of total streamflow for 71 percent of the time during water years 2002-2008). The model also enabled an evaluation of the relative contribution of streamflow from various parts of the watershed.

The model can be further refined by adding algorithms to simulate regulated (or observed) flows and by including remotely-sensed evapotranspiration data. The refined model could be used to estimate possible future streamflow scenarios under changed watershed conditions or in response to drought. The model also can be combined with a groundwater model to further investigate interactions between surface water and groundwater under current and potential future land use and irrigation scenarios. Limitations include uncertainties in the model algorithms; time-series, parameter, and depletions data; calibration to streamflow values that did not include extremely high or low daily streamflow or storm events; and simulation of static soils and land-cover conditions that do not reflect changes caused by periodic forest fires or land use practices .

\section{Acknowledgments}

The authors would like to thank U.S. Geological Survey National Research Program staff Lauren E. Hay, Robert S. Regan, Steven L. Markstrom, and Roland Viger for their assistance with the Precipitation-Runoff Modeling System model. The author also appreciates reviews by Daniel Christiansen, Iowa Water Science Center, and John Risley, Oregon Water Science Center.

\section{References Cited}

\author{
Alley, W.M., and Burns, A.W., 1983, Mixed station exten- \\ sion of monthly streamflow records: Journal of Hydraulic \\ Engineering, American Society of Civil Engineers, v. 109, \\ no. 10 , p. $1272-1284$.
}


Blodgett, D.L., Booth, N.L., Kunicki, T.C., Walker, J.L., and Viger, R.J., 2011, Description and testing of the Geo Data Portal-Data integration framework and Web processing services for environmental science collaboration: U.S. Geological Survey Open-File Report 2011-1157, 9 p.

Caldwell, R.R., and Eddy-Miller, C.A., 2013, Groundwater and surface-water interaction within the upper Smith River Watershed, Montana 2006-2010: U.S. Geological Survey Scientific Investigations Report 2013-5051, 88 p.

Chase, K.J., 2013, Streamflow statistics for unregulated and regulated conditions for selected locations on the Yellowstone, Tongue, and Powder Rivers, Montana and Wyoming, 1928-2002: U.S. Geological Survey Scientific Investigations Report 2013-5173, 183 p., accessed June 20, 2014, at http://dx.doi.org/10.3133/sir20135173.

Chase, K.J., 2011, Development of a precipitation-runoff model to simulate unregulated streamflow in the South Fork Flathead River Basin, Montana: U.S. Geological Survey Scientific Investigations Report 2011-5095, 39 p., accessed June 20, 2014, at http://pubs.usgs.gov/sir/2011/5095/.

Dudley, R.W., 2008, Simulation of the quantity, variability, and timing of streamflow in the Dennys River Basin, Maine, by use of a precipitation-runoff watershed model: U.S. Geological Survey Water-Resources Investigations Report 2008-5100, 44 p., accessed June 20, 2014, at http://pubs. usgs.gov/sir/2008/5100/.

Farnsworth, R.K., Thompson, E.S., and Peck, E.L., 1982, Evaporation atlas for the contiguous 48 United States: U.S. Department of Commerce, National Oceanic and Atmospheric Administration Technical Report NWS 33, 37 p., 4 plates.

Fenneman, N.M., and Johnson, D.W., 1946, Physical divisions of the United States: U.S. Geological Survey, scale 1:7,000,000, 1 sheet.

Harbaugh, A.W., 2005, MODFLOW-2005, the U.S. Geological Survey modular ground-water model-the ground-water flow process: U.S. Geological Survey Techniques and Methods, book 6, chap. A16, [variously paged].

Hay, L.E., and Umemoto, M., 2006, Multiple-objective stepwise calibration using Luca: U.S. Geological Survey OpenFile Report 2006-1323, 25 p.

Hay, L.E., Leavesley, G.H., and Clark, M.P., 2006, Use of remotely-sensed snow covered area in watershed model calibration for the Sprague River, Oregon, in Proceedings of the Third Federal Interagency Hydrologic Modeling Conference, Subcommittee on Hydrology, April 2-6, 2006: Reno, Nev., [variously paged].
Hay, L.E., Leavesley, G.H., Clark, M.P., Markstrom, S.L., Viger, R.J., and Umemoto, M., 2006, Step wise, multiple objective calibration of a hydrologic model for a snowmelt dominated basin: Journal of the American Water Resources Association, v. 42, no. 4, p. 877-890.

Hirsch, R.M., 1982, A comparison of four streamflow record extension techniques: Water Resources Research, v. 18, no. 4, p. 1081-1088.

Jackson, J.A., 1997, Glossary of Geology (4th ed.): Alexandria, Va., American Geological Institute, 769 p.

Jensen, M.E., and Haise, H.R., 1963, Estimating evapotranspiration from solar radiation: Proceedings of the American Society of Engineers, Journal of Irrigation and Drainage, v. 89 , no. IR4, p. 15-41.

Koczot, K.M., Jeton, A.E., McGurk, B.J., and Dettinger, M.D., 2005, Precipitation-runoff processes in the Feather River Basin, northeastern California, with prospects for streamflow predictability, water years 1971-97: U.S. Geological Survey Scientific Investigations Report 2004-5202, 82 p., [Also available at http://pubs.usgs.gov/sir/2004/5202/.]

Laenen, A., and Risley, J.C., 1995, Precipitation-runoff and streamflow-routing models for the Willamette River Basin, Oregon: U.S. Geological Survey Water-Resources Investigations Report 95-4284, 197 p.

Leavesley, G.H., Restrepo, P.J., Markstrom, S.L., Dixon, M., and Stannard, L.G., 2006, The Modular Modeling System (MMS) - User's manual: U.S. Geological Survey OpenFile Report 96-151, $150 \mathrm{p}$.

Leavesley, G.H., Lichty, R.W., Troutman, B.M., and Saindon, L.G., 1983, Precipitation-Runoff Modeling System user's manual: U.S. Geological Survey Water-Resources Investigations Report 83-4238, 207 p.

Linsley, R.K., Kohler, M.A., and Paulhus, J.L.H., 1982, Hydrology for engineers (3rd ed.): New York, McGrawHill, $508 \mathrm{p}$.

Mastin, M.C. and Vaccaro, J.J., 2002, Watershed models for decision support in the Yakima River Basin, Washington: U.S. Geological Survey Open-File Report 02-404, 46 p.

Markstrom, S.L., Niswonger, R.G., Regan, R.S., Prudic, D.E., and Barlow, P.M., 2008, GSFLOW-Coupled ground-water and surface-water flow model based on the integration of the Precipitation-Runoff Modeling System (PRMS) and the Modular Ground-Water Flow Model (MODFLOW-2005): U.S. Geological Survey Techniques and Methods book 6, chap. D1, 240 p. 
Masoner, J.R., Mladinich, C.S., Konduris, A.M., and Smith, S.J., 2003, Comparison of irrigation water use estimates calculated from remotely sensed irrigated acres and state reported irrigated acres in the Lake Altus Drainage Basin, Oklahoma and Texas, 2000 growing season: U.S. Geological Survey Water-Resources Investigations Report 03-4155, 39 p.

Montana Natural Resources Information System, 2010, Digital atlas of Montana: accessed September 21, 2010, at http:// maps2.nris.mt.gov/mapper/.

Moriasi, D. N., Arnold, J.G., Van Liew, M.W., Binger, R.L., Harmel, R.D., and Veith, T.L., 2007, Model evaluation guidelines for systematic quantification of accuracy in watershed simulations: Transactions of the American Society of Agricultural and Biological Engineers, v. 50, no. 3, p. 885-900.

National Climatic Data Center, 2011, Annual climatological summary: accessed November 17, 2011, at http://cdo.ncdc. noaa.gov/ancsum/ACS? coban $=248930$.

Nilges, H.L., and Caldwell, R.R., 2012, Hydrologic data for an investigation of the Smith River Watershed through water year 2010: U.S. Geological Survey Open-File Report 2012-1134, 41 p.

Oregon State University PRISM Group, 2006, United States average monthly or annual precipitation, 1971-2000: Corvallis, Oreg., Oregon State University, accessed March 31, 2009, at http://www.prism.oregonstate.edu/.

Powell, D.S., Faulkner, J.L., Darr, D.R., Zhu, Z., and MacCleery, D.W., 1993, Forest resources of the United States, 1992: Fort Collins, Colo., U.S. Department of Agriculture, Rocky Mountain Forest and Range Experiment Station General Technical Report RM-234, 132 p.

Selker, J..S., Keller, C.K., and McCord, J.T., 1999, Vadose zone processes: Boca Raton, Fla., CRC Press LLC, 339 p.

Thornton, P.E., Thornton, M.M., Mayer, B.W., Wilhelmi, N., Wei, Y., and Cook, R.B., 2012, Daymet-Daily surface weather on a $1 \mathrm{~km}$ grid for North America, 1980-2008: Oak Ridge, Tenn., Oak Ridge National Laboratory Distributed Active Archive Center, accessed July-August 2012, at http://daymet.ornl.gov/daymet_doi.

Thornton, P.E., Running, S.W., and White, M.A., 1997, Generating surfaces of daily meteorology variables over large regions of complex terrain: Journal of Hydrology, v. 190, p. 214-251.

U.S. Department of Agriculture, Natural Resources Conservation Service, 2013a, Soil survey geographic (SSURGO) database for Meagher County, Montana: Natural Resources Conservation Service database, accessed August 15, 2012,

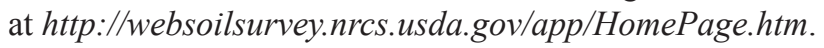

U.S. Department of Agriculture, Natural Resources Conservation Service, 2013b, Soil survey geographic (SSURGO) database for Cascade County, Montana: Natural Resources Conservation Service database, accessed August 15, 2012, at http://websoilsurvey.nrcs.usda.gov/app/HomePage.htm.

U.S. Department of Agriculture, Natural Resources Conservation Service, 1994, State soil geographic (STATSGO) data base-Data use information: Fort Worth, Tex., U.S. Department of Agriculture, no. 1492, 113 p.

U.S. Department of the Interior Bureau of Reclamation, 2012, Missouri River Basin depletions database, Great Plains Region: U.S. Department of the Interior Bureau of Reclamation, Great Plains Regional Office, September 2012, $128 \mathrm{p}$.

U.S. Department of the Interior Bureau of Reclamation, 2005, A study to determine the historic and present-level streamflow depletions in the Missouri River basin for the period 1929 to 2002: Billings, Mont., U.S. Department of the Interior Bureau of Reclamation, Water Resources Service Group, Great Plains Regional Office, January 2005, [variously paged].

U.S. Department of the Interior Bureau of Reclamation, 1999, A study to determine the historic and present-level streamflow depletions in the Missouri River basin above Hermann, Missouri: Billings, Mont., U.S. Department of the Interior Bureau of Reclamation, Appendix F-C of Upper Mississippi River system flow frequency study, Water Resources Service Group, Great Plains Regional Office, August 1999, [variously paged].

U.S. Geological Survey, 2012a, Water data for the Nation: U.S. Geological Survey database, accessed October 19, 2012, at http://waterdata.usgs.gov.

U.S. Geological Survey, 2012b, Precipitation-Runoff Modeling System (PRMS) documentation: U.S. Geological Survey, accessed October 24, 2012, at http://wwwbrr.cr.usgs. gov/projects/SW_MoWS/PRMS.html.

U.S. Geological Survey, 2000, National land cover data for Montana, vector format: U.S. Geological Survey, accessed March 16, 2009, at http://nris.mt.gov/nsdi/nris/nlcd/ nlcdvector.asp.

U.S. Geological Survey, 1999, National elevation dataset: U.S. Geological Survey database, accessed September 1, 2006, at http://ned.usgs.gov/.

Viger, R.J., and Leavesley, G.H., 2007, The GIS Weasel user's manual: U.S. Geological Survey Techniques and Methods, book 6, chap. B4, 201 p., [Also available online at http:// pubs.usgs.gov/tm/2007/06B04/]. 
Ward-Garrison, C., Markstrom, S.L., and Hay, L.E., 2009, Downsizer - A graphical user interface-based application for browsing, acquiring, and formatting time-series data for hydrologic modeling: U.S. Geological Survey Open-File

Report 2009-1166, 27 p.,[Also available at http://pubs.usgs. gov/of/2009/1166/.]

Wolock, D.M., 1997, STATSGO soil characteristics for the conterminous United States: U.S. Geological Survey OpenFile Report 97-656, 17 p.

Zhu, Zhiliang, 1994, Forest density mapping in the lower 48 states-A regression procedure: New Orleans, La., U.S. Department of Agriculture, Forest Service, Southern Forest Experiment Station, Research Paper SO-280, 11 p.

Zhu, Zhiliang, and Evans, D.L., 1994, U.S. forest types and predicted percent forest cover from AVHRR data: Photogrammetric Engineering and Remote Sensing, v. 60, no. 5, p. 525-531. 
Appendix 
Appendix 1. Historical depletion data for the Smith River, Montana, Calendar Years 1929-2007.

[Depletions for 1929-2007 from Bureau of Reclamation (Clayton Jordan, U.S. Department of Interior Bureau of Reclamation, written commun., 2011; U.S. Department of Interior Bureau of Reclamation, 2012). Depletion data are rounded to 1 decimal place, as provided by Bureau of Reclamation; differences in significant figures do not imply differences in accuracy. Positive depletions indicate decreases in streamflow relative to unregulated conditions, and negative depletions indicate increases in streamflow relative to unregulated conditions. KAF, kilo acre-foot]

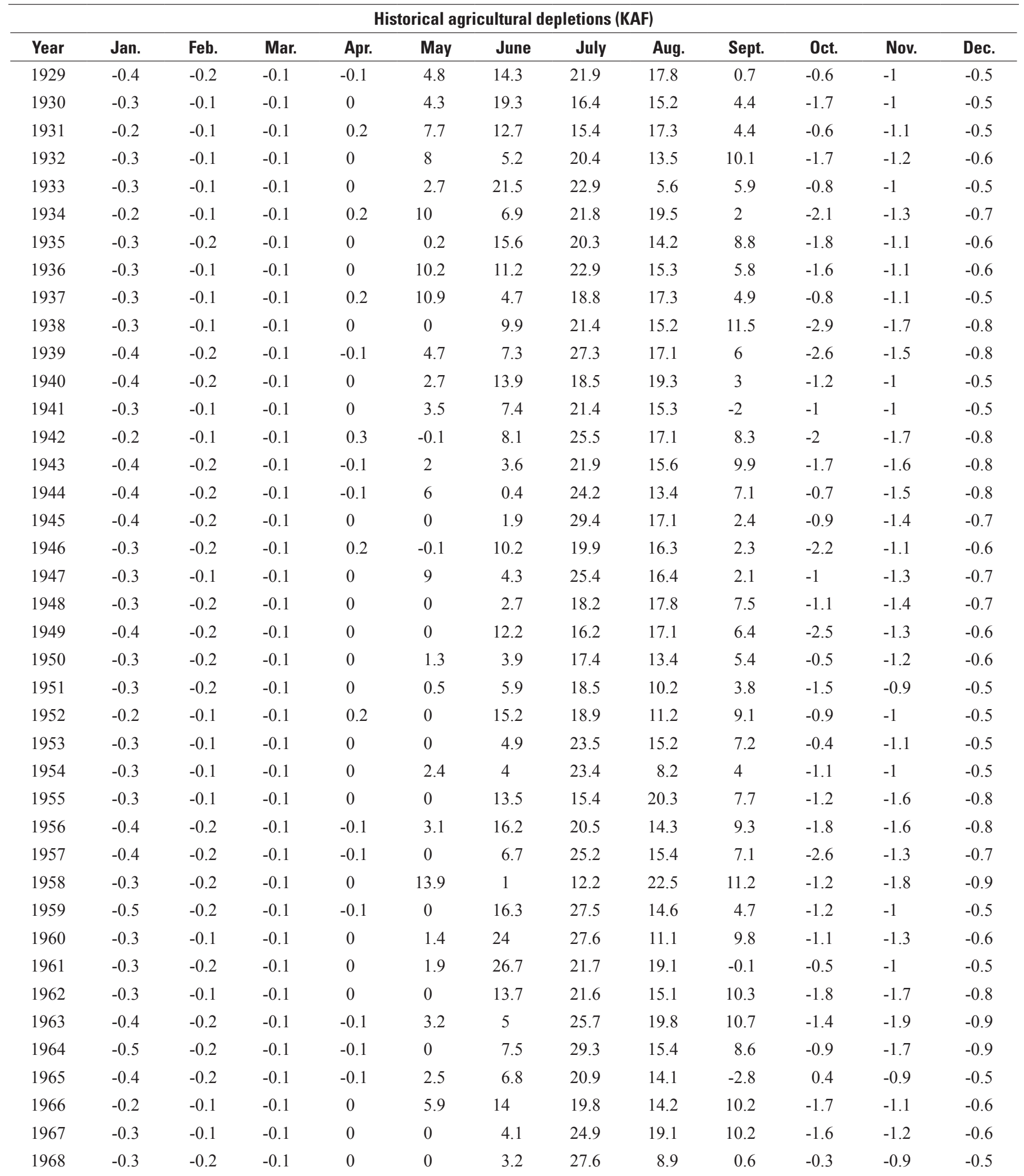


Appendix 1. Historical depletion data for the Smith River, Montana, Calendar Years 1929-2007.—Continued

[Depletions for 1929-2007 from Bureau of Reclamation (Clayton Jordan, U.S. Department of Interior Bureau of Reclamation, written commun., 2011; U.S. Department of Interior Bureau of Reclamation, 2012). Depletion data are rounded to 1 decimal place, as provided by Bureau of Reclamation; differences in significant figures do not imply differences in accuracy. Positive depletions indicate decreases in streamflow relative to unregulated conditions, and negative depletions indicate increases in streamflow relative to unregulated conditions. KAF, kilo acre-foot]

\begin{tabular}{|c|c|c|c|c|c|c|c|c|c|c|c|c|}
\hline \multicolumn{13}{|c|}{ Historical agricultural depletions (KAF) } \\
\hline Year & Jan. & Feb. & Mar. & Apr. & May & June & July & Aug. & Sept. & Oct. & Nov. & Dec. \\
\hline 1969 & -0.2 & -0.1 & -0.1 & 0 & 2.8 & 2.7 & 20.3 & 19.3 & 9.6 & -1.6 & -1.1 & -0.6 \\
\hline 1970 & -0.3 & -0.1 & -0.1 & 0 & 2.1 & 10.7 & 20 & 18.6 & 6 & -1.2 & -1 & -0.5 \\
\hline 1971 & -0.3 & -0.1 & -0.1 & 0 & 0 & 13.2 & 21.6 & 17.1 & 5.2 & -0.7 & -1 & -0.5 \\
\hline 1972 & -0.3 & -0.1 & -0.1 & 0 & 1.1 & 19.9 & 15.7 & 12.5 & 8 & -1.8 & -1.4 & -0.7 \\
\hline 1973 & -0.3 & -0.2 & -0.1 & 0 & 8.6 & 17.7 & 23.9 & 15.2 & 2.9 & -1.1 & -1 & -0.5 \\
\hline 1974 & -0.3 & -0.1 & -0.1 & 0 & 0 & 24.1 & 25.4 & 7 & 9 & -1.3 & -1.6 & -0.8 \\
\hline 1975 & -0.4 & -0.2 & -0.1 & -0.1 & 0 & 5 & 23.3 & 13.3 & 10.9 & -2.8 & -1.4 & -0.7 \\
\hline 1976 & -0.4 & -0.2 & -0.1 & 0 & 9.7 & 6.7 & 22.7 & 13.3 & 10.7 & -1.6 & -1.7 & -0.8 \\
\hline 1977 & -0.4 & -0.2 & -0.1 & 0.3 & 0.6 & 21.3 & 18 & 8.9 & 1.3 & -0.2 & -1.1 & -0.5 \\
\hline 1978 & -0.3 & -0.1 & -0.1 & 0 & 0 & 19.8 & 17.2 & 16 & 4.2 & -0.6 & -1.4 & -0.7 \\
\hline 1979 & -0.4 & -0.2 & -0.1 & 0 & 6.1 & 14.2 & 20.2 & 19 & 11.4 & -1.6 & -1.3 & -0.7 \\
\hline 1980 & -0.3 & -0.2 & -0.1 & 0 & 0 & 7.7 & 27.7 & 13.1 & 8.2 & -2.7 & -1.4 & -0.7 \\
\hline 1981 & -0.3 & -0.2 & -0.1 & 0.6 & -0.1 & 17.6 & 24.4 & 17.4 & 12.1 & -2.8 & -1.9 & -0.9 \\
\hline 1982 & -0.5 & -0.2 & -0.1 & -0.1 & 0 & 11.9 & 26.6 & 20.8 & 1.1 & -1.2 & -1.4 & -0.7 \\
\hline 1983 & -0.4 & -0.2 & -0.1 & 0 & 0 & 14.1 & 15.5 & 22 & 3.9 & -0.6 & -1.5 & -0.7 \\
\hline 1984 & -0.4 & -0.2 & -0.1 & -0.1 & 10 & 14 & 25 & 13.8 & 2.7 & -2.4 & -1.2 & -0.6 \\
\hline 1985 & -0.3 & -0.2 & -0.1 & 0 & 2.2 & 18.6 & 25.3 & 6.4 & -2.5 & -0.9 & -0.8 & -0.4 \\
\hline 1986 & -0.2 & -0.1 & 0 & 0 & 3.5 & 18.8 & 9.9 & 16.5 & -2.5 & -0.5 & -0.9 & -0.5 \\
\hline 1987 & -0.2 & -0.1 & -0.1 & 0 & 0 & 18.3 & 12 & 13.6 & 7.2 & -0.7 & -1.4 & -0.7 \\
\hline 1988 & -0.4 & -0.2 & -0.1 & 0 & 0 & 19.1 & 18.3 & 15.1 & 2.9 & -1.3 & -1.2 & -0.6 \\
\hline 1989 & -0.3 & -0.2 & -0.1 & 0 & 0.6 & 10.7 & 20.5 & 5.8 & 7.5 & -1.9 & -1.1 & -0.5 \\
\hline 1990 & -0.3 & -0.1 & -0.1 & 0 & 0 & 13.2 & 17.1 & 9.2 & 13.2 & -1.8 & -1.5 & -0.8 \\
\hline 1991 & -0.4 & -0.2 & -0.1 & -0.1 & 0 & 4.2 & 19.7 & 15.8 & 1.7 & -1.3 & -1 & -0.5 \\
\hline 1992 & -0.2 & -0.1 & -0.1 & 0 & 0 & 8.6 & 10 & 11.3 & 6.4 & -1.9 & -0.9 & -0.5 \\
\hline 1993 & -0.2 & -0.1 & -0.1 & 0 & 0 & 4.9 & 3.4 & 3.9 & 6.1 & -1.1 & -0.6 & -0.3 \\
\hline 1994 & -0.1 & -0.1 & 0 & 0 & 0.3 & 16.7 & 17.9 & 14.7 & 10.3 & -2.5 & -1.5 & -0.8 \\
\hline 1995 & -0.4 & -0.2 & -0.1 & -0.1 & 0 & 5.6 & 9.9 & 18.1 & 2.8 & -1.8 & -0.9 & -0.5 \\
\hline 1996 & -0.2 & -0.1 & -0.1 & 0 & 0 & 14.9 & 16.3 & 14.2 & 0.8 & -1.3 & -1 & -0.5 \\
\hline 1997 & -0.2 & -0.1 & -0.1 & 0 & 0 & 2.7 & 14.2 & 13.2 & 9.6 & -2 & -1.2 & -0.6 \\
\hline 1998 & -0.3 & -0.2 & -0.1 & 0 & 0 & 3.9 & 16 & 13.5 & 9.2 & -1.3 & -1.3 & -0.7 \\
\hline 1999 & -0.3 & -0.2 & -0.1 & 0 & 0 & 6.8 & 17.8 & 14.2 & 6.2 & -1 & -1.3 & -0.6 \\
\hline 2000 & -0.3 & -0.2 & -0.1 & 0 & 0 & 6.2 & 21.4 & 16.6 & 3.4 & -2.2 & -1.1 & -0.5 \\
\hline 2001 & -0.3 & -0.1 & -0.1 & 0 & 6 & 5.3 & 13.3 & 18.1 & 6.2 & -1.6 & -1.3 & -0.6 \\
\hline 2002 & -0.3 & -0.2 & -0.1 & 0 & 0 & 2.9 & 19.4 & 10.2 & 6 & -1.5 & -1 & -0.5 \\
\hline 2003 & -0.3 & -0.1 & -0.1 & 0 & 0 & 15 & 23.5 & 14.9 & 3.7 & -1.5 & -1.3 & -0.6 \\
\hline 2004 & -0.3 & -0.2 & -0.1 & 0 & 0 & 5.5 & 21.7 & 9.1 & 4.5 & -1.1 & -1 & -0.5 \\
\hline 2005 & -0.3 & -0.1 & -0.1 & 0 & 1.4 & 2.4 & 20 & 13.3 & 6.2 & -1.6 & -1.1 & -0.6 \\
\hline 2006 & -0.3 & -0.1 & -0.1 & 0 & 3.8 & 9.4 & 21.5 & 13.2 & 2.1 & -2 & -1 & -0.5 \\
\hline 2007 & -0.3 & -0.1 & -0.1 & 0 & 0 & 10.7 & 19 & 14.3 & 3.8 & -1.5 & -1.1 & -0.6 \\
\hline
\end{tabular}




\section{Publishing support provided by:}

Rolla Publishing Service Center

For more information concerning this publication, contact: Director, USGS Montana Water Science Center

3162 Bozeman Avenue

Helena, MT 59601

(406) 457-5900

Or visit the Montana Water Science Center Web site at: http://mt.water.usgs.gov/ 

을.

产. 